\title{
A Hyperspectral Study (V-NIR-SWIR) of the Nechalacho REE-Nb-Zr Deposit, Canada
}

\author{
Volker Möller $^{a *}$ and Anthony E. Williams-Jones ${ }^{\mathrm{a}}$ \\ ${ }^{\mathrm{a} E a r t h}$ and Planetary Sciences, McGill University, 3450 University Street, Montreal, QC H3A 0E8, Canada \\ * Corresponding author, volker.moeller@mail.mcgill.ca
}

\section{Abstract}

This paper reports the results of a visible, near-infrared and short wave infrared (V-NIR-SWIR) spectroscopic study of the Nechalacho rare earth element (REE)-Nb-Zr deposit (Canada), associated rare metal pegmatites and select samples from other REE deposits. The zoning of minerals produced by hydrothermal alteration is traced using V-NIR-SWIR spectroscopic measurements in combination with geological, geochemical and mineralogical data. The minerals detected using V-NIR-SWIR spectroscopy (analcime, ankerite, phlogopite, chlorite, illite, REE-fluorocarbonates) display complex distributions that were strongly controlled by the pathways and composition of multiple stages of hydrothermal fluids together withas well as the precursor lithology. Magmatic-hydrothermal analcime \pm amphibole alteration was overprinted by regional phlogopite + magnetite + illite + ankerite + chlorite + REE-fluorocarbonate replacement (main-stage). A qualitative mass change analysis indicates that the main-stage alteration event was associated with significant gains in $\mathrm{Mg}$ and losses of $\mathrm{Na}$ at temperatures of $\sim 300{ }^{\circ} \mathrm{C}$, as indicated by the presence of phengitic to muscovitic illite. Low-temperature ankerite \pm chlorite alteration was mainly fluid-controlled and associated with the formation of hydrothermal REE-fluorocarbonates that crystallized as a result of the interaction of aqueous-carbonic hydrothermal fluids with eudialyte syenite protoliths, locally leading to leaching and redeposition of light REE. The ankerite \pm chlorite alteration also affected pegmatites peripheral to the Nechalacho intrusion and surrounding hydrothermally altered zones. Analysis of a variety of REE-mineral specimens and geochemically characterized bulk rock samples confirms that the relative depths of the 741 and $864 \mathrm{~nm}$ NIR absorption features of Nd can be used as qualitative and quantitative proxies for the detection of the REE. In combination with fast measurement and processing capabilities, this allows field-based V-NIR-SWIR spectroscopy to be deployed as a powerful tool for regional and deposit-scale REE exploration, deposit characterization and mine production grade control. 


\section{Keywords}

2 Nechalacho REE-Nb-Zr deposit; hyperspectral; V-NIR-SWIR spectroscopy; rare earth elements

\section{1. Introduction}

$4 \quad$ Field-based visible and near infrared (V-NIR) and short wave infrared (SWIR) spectroscopy are deployed routinely to characterize the alteration mineralogy associated with porphyry $\mathrm{Cu}(-\mathrm{Au}-\mathrm{Mo})$ and epithermal $\mathrm{Au}$ deposits as a vector to mineralization (e.g., Harraden et al., 2013), and have been successfully applied to VHMS deposits (e.g., Herrmann et al., 2001; Jones et al., 2005). Considerably less attention has been devoted to rare earth element (REE, including Y and the lanthanoids from La to Lu) deposits (e.g., Rowan et al., 1986; Turner et al., 2014), which pose particular challenges in exploration and mining owing to their exotic ore and alteration mineralogy. Instead, for REE and $\mathrm{Nb}$ deposits, handheld X-ray fluorescence (XRF) analysis has been a reliable field method of choice (e.g., Simandl et al., 2014a; 2014b). Here, we evaluate the exploration and grade control applicability of V-NIR-SWIR spectroscopy for one of the world's largest high-grade REE and $\mathrm{Nb}$ resources, the Nechalacho Rare Metal Deposit (Northwest Territories, Canada; 13 Fig. 1Fig. 1). By studying mineralogically characterized (scanning electron microscopy, electron microprobe) and 14 assayed reference samples from the Nechalacho deposit, we identify the alteration (ankerite, chlorite, biotite, illite) and 15 ore mineralogy (bastnäsite-[Ce], synchysite-[Ce], parisite-[Ce]) using hyperspectral data. The data set is augmented by 16 mineral samples from other selected REE deposits and occurrences (Mountain Pass, Strange Lake, Mont Saint-Hilaire, 17 Kipawa).

Spectroscopy in the V-NIR-SWIR wavelength range $(\sim 400$ to $3000 \mathrm{~nm})$ of the electromagnetic spectrum takes advantage of characteristic absorption wavelengths of molecular bonds in minerals (e.g., $\mathrm{Al}-\mathrm{OH}, \mathrm{Fe}-\mathrm{OH}, \mathrm{C}-\mathrm{O}$ ), but can also detect the elemental absorptions of $\mathrm{Fe}^{2+}, \mathrm{Fe}^{3+}$ and the REE. As a field method with very low measurement times (an $<1 \mathrm{~s}$ acquisition time of $<1$ is pessiblefeasible), it facilitates the systematic and detailed collection of downhole and outcrop-wide mineralogical profiles. Common minerals that can be detected include phyllosilicates, amphiboles, epidote, and-carbonates, sulfates and hydroxyl-bearing phases (Hunt and Ashley, 1979). The REE ${ }^{3+}$ ions (with the exception of $\mathrm{Ce}^{3+}, \mathrm{Yb}^{3+}$ and $\left.\mathrm{Y}^{3+}\right)$ have sharp absorptions in the visible spectrum ( 400 to $700 \mathrm{~nm}$ ) that are caused by $f \rightarrow f$ transitions of the $4 f$ electrons (Dieke and Crosswhite, 1963; White, 1967; Rowan et al., 1986; McGill, 2000). The absorption behavior is only weakly influenced by interactions with ligands owing to shielding of the $4 \mathrm{f}$ electrons 
exhibit this absorption. The sharp absorption features of the REE render them interesting materials for optical applications such as in the Nd-YAG laser. White (1967) presented V-NIR-SWIR data for the REE, but the resolution was relatively low and the spectra were not continuous.

The Nechalacho deposit consists of hydrothermally altered eudialyte syenites that are hosted by a layered nepheline syenite intrusion, the Nechalacho Layered Suite (Möller and Williams-Jones, 2016a). Eudialyte group minerals are complex REE-Nb-zirconosilicates; we use the term eudialyte for simplicity. With 61.9 Mt of measured and indicated resources grading 1.64 wt. \% REE-oxide, of which $21.5 \%$ are heavy REE (Y, Eu to Lu) and 0.41 wt. \% $\mathrm{Nb}_{2} \mathrm{O}_{5}$, the Basal Zone is the largest, highest-grade and most heavy REE-enriched mineralized layer in the deposit (Avalon Rare Metals Inc., 2013). The entire deposit, however, is much larger. Including the Upper Zone, 109 Mt of measured and indicated (1.59 wt. \% REE-oxide) and $160 \mathrm{Mt}$ of inferred resources (1.38 wt. \% REE-oxide) have been defined by drilling (Avalon Rare Metals Inc., 2013). Several recent studies have characterized the ore and gangue mineralogy of the Nechalacho rare metal deposit (Sheard et al., 2012; Timofeev and Williams-Jones, 2015; Möller and Williams-Jones, 2017, in revision). The nearby T-Zone pegmatite contains high-grade Be and REE mineralization (Trueman et al., 1988), and polylithionite, a relatively rare trioctahedral $\mathrm{Li}$-mica with the formula $\mathrm{KLi}_{2} \mathrm{AlSi}_{4} \mathrm{O}_{10}(\mathrm{~F}, \mathrm{OH})_{2}$ that occurs in association with peralkaline intrusions, is a major mineral in the T- and S-Zones (Černý and Trueman, 1985).

This study uses field-portable V-NIR-SWIR spectroscopy to identify cryptic hydrothermal alteration zoning in the Nechalacho deposit, associated rare metal pegmatites and their host rocks. By studying this geologically, mineralogically and geochemically well-characterized deposit, we also evaluate the potential to use outcrop and drill core hyperspectral studies as an exploration tool for REE-Nb deposits elsewhere. The hyperspectral data are supported by a framework of analyzed reference specimens and whole rock and mineral data that provide a geochemical context and allow interpretation of the hydrothermal controls on the alteration of the deposit and its host rocks.

\section{Geological and mineralogical overview}

The $2176 \mathrm{Ma}$ (concordant U-Pb zircon age; Möller and Williams-Jones, 2016b) Nechalacho Layered Suite is part of the Blatchford Lake Igneous Complex and intruded the Thor Lake Syenite, a riebeckite-alkali feldspar-quartz-syenite (Fig. 2). From top to bottom, the Nechalacho Layered Suite consists of 14 units, numbered sequentially downwards (Möller and Williams-Jones, 2016a). The primary magmatic mineralogy of the Nechalacho Layered Suite consists 
mainly of aegirine (clinopyroxene), annite (biotite), eudialyte, nepheline, sodalite, K-feldspar and albite, as listed in Table 1Table 1 (refer to Table 2 lists-forsome of the mineral formulae). Magmatic annite and aegirine are close to their end member compositions (Möller and Williams-Jones, 2016a). Magmatic-hydrothermal alteration by deuteric fluids caused the formation of analcime at the expense of nepheline and sodalite and locally replacement of aegirine by sodic amphibole (Möller and Williams-Jones, 2016a). Owing to a strong late (1835 - $1871 \mathrm{Ma}$; Möller and Williams-Jones, 2016b) hydrothermal alteration overprint (main-stage alteration; Möller and Williams-Jones, 2017, in revision), a variety of secondary ore and gangue minerals formed in the Nechalacho Layered Suite, destroying much of the primary mineralogy (Tables 1, 2). The main-stage alteration included the formation of hydrothermal biotite, which has an average composition of $\mathrm{K}_{0.9} \mathrm{Mg}_{1.9} \mathrm{Fe}_{1.0} \mathrm{Si}_{3.0} \mathrm{Al}_{1.1} \mathrm{~F}_{0.9}(\mathrm{OH})_{1.0}$ and ranges in $\mathrm{Mg} /(\mathrm{Mg}+\mathrm{Fe})$ from 0.51 to 0.82 ( $\mathrm{Möller} \mathrm{and}$ Williams-Jones, 2017, in revision). Abundant hydrothermal ankerite-ferroan dolomite solid solution series (for simplicity, use-ankerite) is also part of the main-stage paragenesis and has the composition $\mathrm{Ca}_{1.0-1.6} \mathrm{Fe}_{0.14-0.56} \mathrm{Mg}_{0.41-}$ ${ }_{0.83} \mathrm{Mn}_{0.01-0.07}\left(\mathrm{CO}_{3}\right)_{2}$ (Möller and Williams-Jones, 2016b). The REE and $\mathrm{Nb}$ are concentrated mainly in two hydrothermally altered eudialyte syenite layers, the Upper Zone (unit NLS-5) and the Basal Zone (NLS-6). In them, interstitial and cumulus eudialyte was completely replaced hydrothermally by various REE- and REE-Nb-minerals, of which fergusonite-(Y) and bastnäsite-(Ce) are dominant (Tables 1, 2). In addition, there are vein and pervasively disseminated REE-mineralized zones containing bastnäsite-(Ce) and allanite-(Ce). The T- and S-Zones are quartzofeldspathic pegmatites enriched in phenakite, bastnäsite-(Ce), columbite-(Fe,Mn) and polylithionite. These pegmatites have been interpreted to represent small bodies of magma extracted from the Nechalacho Layered Suite during the final stages of its crystallization (Möller and Williams-Jones, 2016a). Located on the Canadian shield, the Nechalacho deposit and its host rocks did not experience any chemical weathering.

\section{Alteration mineralogy}

The alteration mineralogy of the Nechalacho Layered Suite varieds as a result of an interplay between a heterogeneous magmatic precursor lithology and compositionally variable hydrothermal fluids (magmatic-hydrothermal and several stages of later hydrothermal fluids). The dominant alteration minerals are phlogopitic biotite (i.e., Mg-enriched biotite instead of magmatic iron-end member annite), magnetite, quartz, ankerite, fluorite, chlorite, illite, zircon and hematite (see Table 2 for mineral formulae). We use the term illite for dark blue to green mica, likely of the dioctahedral series muscovite, celadonite, aluminoceladonite and hydromuscovite (see Rieder et al., 1998; Meunier and Velde, 2004); 
zircon and hematite. Magmatic sodalite was partially or completely replaced by blue to green hydrothermal Fe- and 2 Mg-enriched illite in all altered units of the syenite suite (Fig. 3Fig. $3 \mathrm{~A}$ ). The illite alteration is dominant in unit NLS3 1, as it is sodalite-rich, but was also observed in sodalite-enriched layers and units throughout the syenite suite. As the 4 replacement was pseudomorphic, pseudohexagonal crystal cross-sections filled by illite after sodalite are commonly 5 observed (Fig. 3Fig. 3 A). Riebeckite, a sodic amphibole, is observed rarely as a hydrothermal replacement of aegirine 6 (Fig. 3Fig. 3 B, C). This may reflect very limited magmatic-hydrothermal alkaline alteration or the destruction of this 7 alteration type by later pervasive alteration. The most common alteration type in units NLS-4 to -6 (i.e., the REEenriched units) is biotitization associated with hydrothermal quartz and magnetite (Fig. 3Fig. $3 \mathrm{E}, \mathrm{G}, \mathrm{H}, \mathrm{I}$ ). In thin section, it is evident that Fe-Mg-biotite consistently replaced K-feldspar (Fig. 4Fig. $4 \mathrm{~A}, \mathrm{~B}$ ). This alteration type (the main-stage alteration) is syn-genetic with the pseudomorphic replacement of eudialyte by zircon, quartz and a variety of REE- and REE-Nb minerals in the Upper and Basal Zones of the deposit (Fig. 3Fig. 3 E, F). Less commonly, chlorite formed instead of biotite (Fig. 3Fig. 3 F). Chlorite occurs together with ankerite, fluorite, quartz and bastnäsite(Ce) in the zones of strongest hydrothermal alteration (Fig. 4Fig. 4 C, D, F) and EDX analyses indicate that the chlorite is Mg-enriched; it thus likely contains a clinochlore component. Macroscopic brick-red bastnäsite-(Ce) is the most easily identified hydrothermal REE-mineral in drill core, and commonly occurs together with hydrothermal biotite or chlorite (Fig. 3Fig. 3 F, G, H). Hy Bin pegmatite is similar in appearance to that in the Nechalacho Layered Suite (Fig. 3Fig. 3 D). Hydrothermal ankerite + quartz alteration also occurs without the other hydrothermal minerals in zones where the magmatic feldspars and aegirine are pristine (Fig. 4 Fig. 4 E). With the exception of late calcite veins crosscutting the alteration assemblage of the Nechalacho Layered Suite, ankerite is the dominant carbonate; its average formula corresponds to

\section{Materials and methods}

Prior to field analyses, the feasibility of the project was tested on reagent-grade pure REE-oxide powders (Table 3Fable 3), thin section off-cuts from drill core and outcrop samples from the Nechalacho Layered Suite, surrounding satellite REE-mineralization zones, pure mineral specimens from the Redpath Museum at McGill University and several samples from other deposits. All outcrop sample and drill hole coordinates are given in Electronic Appendix A. 
The pure REE-oxide powders are trivalent $\mathrm{REE}_{2} \mathrm{O}_{3}$ and colorless or lightly colored, except for $\mathrm{CeO}_{2}$ (colorless) and the mixed oxidation state oxides, $\mathrm{Pr}_{6} \mathrm{O}_{11}$ and $\mathrm{Tb}_{4} \mathrm{O}_{7}$ (both black, Table 3Table 3). Samples from the Strange Lake intrusion were provided by A. Gysi. A sample of nepheline syenite containing light-brown translucent eudialyte was collected from the Poudrette quarry in the Mont Saint-Hilaire intrusion (Quebec, Canada) in 2010. Eudialyte from the Kipawa deposit in Quebec was obtained commercially.

Bulk rock geochemical samples were analyzed by ALS Laboratories (Vancouver, Canada) and ACME Laboratories (Vancouver) via a lithium metaborate/tetraborate fusion and dilute nitric acid digestion followed by ICPOES analysis for major elements and ICP-MS analysis for trace elements, including the REE. Energy-dispersive X-ray spectroscopic (EDS) and quantitative wavelength-dispersive X-ray spectroscopic (WDS) analyses of hydrothermal amphibole were performed with a JEOL JXA 8900L electron microprobe, (which is equipped with five WDS spectrometers), at the Department of Earth and Planetary Sciences, McGill University. The WDS data reduction was performed using the ZAF correction procedure. Further details for the WDS analyses are given in Electronic Appendix B. For X-ray diffraction (XRD) analyses, powders were pipetted onto sample holders. All samples were analyzed after each step of drying in air, glycolation and heating to $300{ }^{\circ} \mathrm{C}$. The XRD data were collected using a $0.2^{\circ}$ step resolution on a Siemens D-5000 (DRX) diffractometer (Co K $\alpha$ ) equipped with a Sol-X detector at Université du Québec à Montréal. The magnetic susceptibility of drill core samples was measured using a handheld KT-9 Kappameter (Exploranium G.S. Ltd.) that was set to the appropriate drill core diameter. The instrument measures the oscillator (10 $\mathrm{kHz} \mathrm{LC})$ frequency in air for $1 \mathrm{~s}$ and in contact with the examined material for $0.5 \mathrm{~s}$, and calculates the susceptibility in SI units from the frequency difference.

All hyperspectral measurements in the laboratory and in the field were performed using a Terraspec $4 \mathrm{Hi}-\mathrm{Res}$ mineral spectrometer. The portable spectrometer has a wavelength range of 350 to $2500 \mathrm{~nm}_{2}$ which covers the visible light (V), near-infrared (NIR) and short wave infrared (SWIR) segments of the electromagnetic spectrum (Fig. 5Fig. 5). The spectral resolution is 3 and $6 \mathrm{~nm}$, and the sampling interval 1.4 and $2 \mathrm{~nm}$, respectively in the V-NIR and SWIR regions. The setup consists of a main unit that houses the light sources and detectors, which are connected to a probe via a fiber-optic cable (Fig. 6Fig. 6). A laptop computer controls the instrument and acquires the spectral reflectance data (relative intensity). The Hi-Brite contact probe was used for all solid samples (hand samples, drill core with PQ, HQ and NQ diameters); for powders we used the MugLight accessory. 
Spectra cCollection of spectraollection and calibrations were performed with the $\mathrm{RS}^{3}$ software (PANalytical / ASD Inc.). A Spectralon white reference panel (Labsphere) was used periodically to calibrate the spectrometer, and accuracy was monitored using a Mylar wavelength reference standard with dual-pass absorption features $( \pm 1 \mathrm{~nm})$ at $1128.7,1660.1,1952.9,2131.6$ and $2256.0 \mathrm{~nm}$. The sample count was 10 for the unknown spectra (2.5 seconds), 25 for 5 the white reference and 10 for the dark current. Automated mineral identification and spectral calculations were 6 performed with the software, The Spectral Geologist (TSG) Pro 7.1 (CSIRO/AusSpec International) using standard and 7 custom libraries for mineral matching. The $\underline{\mathrm{Up}}$ to two most abundant minerals were automatically identified from the 8 spectra using The Spectral Assistant (TSA) version 6.0 algorithm in the TSG software, which computes simulated 9 mineral mixtures based on a reference library, compares them to the unknown spectra, and chooses the result with the 10 lowest error (Berman et al., 1999; Berman et al., 2011; CSIRO, 2013). Automated-The automated results-result outputs 11 of the TSA were routinely checked manually. Spectra of drill core were collected at intervals ranging from 0.5 to 2 m. 12 Several spectra were collected at the same depth if the core samples were heterogeneous; and crosscutting late crosscutting veins were avoided.

\section{5. Results}

15 5.1. Mass changes during alteration (unit NLS-1)

16 To evaluate the chemical effects of hydrothermal alteration on the major element rock composition, samples from unit 17 NLS-1 (Roof Sodalite Syenite) were analyzed (see Electronic Appendix C for the analytical data and methods). This 18 unit was selected because it is easily identified by its distinct texture and because samples that experienced very minor 19 alteration are available. Owing to the primary modal variations (which result in large variations in major element contents), a mass balance could be determined only on a semi-quantitative basis. This semi-quantitative treatment indicates that $\mathrm{Mg}, \mathrm{K}$ and $\mathrm{Si}$ were gained during alteration and $\mathrm{Ca}, \mathrm{Fe}$ and $\mathrm{Na}$ were lost (Fig. 7; see figure subtextcaption for an explanation of the diagram construction). mMinor gains in $\mathrm{Fe}$ and $\mathrm{Al}$ are inconsistent with petrographic observations and represent an artifact of the primary compositional variability). The mass changes are were greatest for $\mathrm{Mg}$, which is absent in the fresh rocks, and for $\mathrm{Na}$, which was highly enriched in primary magmatic sodalite but was lost due to the replacement of sodalite by illite (Fig. 7). 
2 Powdered samples of dark blue to green illite from pseudomorphs after sodalite were analyzed using X-ray diffraction 3 prior to the hyperspectral analyses in order to identify the member(s) of the illite series. All the samples are from unit 4 NLS-1, except L12-475-246.3, which is from a sodalite-rich layer in unit NLS-8. Bulk rock analyses and the mass5 balance considerations, in combination with petrographic observations (absence of other Mg-bearing minerals) 6 indicate that the illite is Mg-enriched. The samples have strong 10 $\AA$ reflections (001 d-spacing), varying from 10.04 7 to $10.10 \AA$ (Fig. 8Fig. 8). The full width at half maximum intensity (FWHM) of the $10 \AA$ reflection is 0.23 to 0.50 ( ${ }^{\circ} 2 \theta$ 8 Co K $\alpha$; Table 4Table 4). A FWHM $>0.25^{\circ}$ is characteristic of illite, although there is no sharp boundary to-with 9 muscovite (Meunier and Velde, 2004). The narrow $10 \AA$ peaks indicate that the illite approaches the phengite or 10 muscovite structure (Table 4Table 4). This is consistent with a low-grade metamorphic (high "anchizone" to "epizone" 11 in the classification of Kübler; e.g., Kübler and Jaboyedoff, 2000; i.e., $\mathrm{T} \geq \sim 300{ }^{\circ} \mathrm{C}$ ) or a hydrothermal origin (e.g., 12 Duba and Williams-Jones, 1983). Temperatures estimated from the FWHM of the illite using the empirical calibrations 13 of Ji and Browne (2000) range from $\sim 270$ to $\sim 320^{\circ} \mathrm{C}$. After treatment with glycol, there was no broadening of the 14 peaks, indicating that there is no interlayered smectite. No changes were observed upon heating the samples to $300{ }^{\circ} \mathrm{C}$ 15 (Electronic Appendix D). The Mg-enriched nature of the phengite-phengitic illite indicates that it may be celadonite or 16 aluminoceladonite but mineral chemical analyses would be required to allow a further specification. The XRD 17 identification agrees with the V-NIR-SWIR analyses, which variably indicate that it is a phengitic, paragonitic or 18 muscovitic illite, phengite or muscovite; Sections 5.5.3 and 5.6).

\section{5.3. Composition of hydrothermal amphibole}

20 The composition of magmatic-hydrothermal replacement-amphibole was analyzed by electron microprobe in order to 21 facilitate interpretation of the hyperspectral data. These analyses showed that the dark-blue hydrothermal amphibole, 22 which replaced magmatic aegirine in unit NLS-2 (sample L10-251-335.7, Fig. 3Fig. 3 B; sample L10-251-339.2), has a 23 composition close to that of end member riebeckite (Table 5Table 5, see Electronic Appendix E for the full data set). 24 Rare, fine-grained hydrothermal amphibole in unit NLS-11 (sample L09-194-635.3) is arfvedsonite (Table 5Table 5). 25 The mineral formulae were calculated using the PROBE-AMPH spreadsheet of Tindle and Webb (1994).

Commented [w1]: There is no point in inviting the criticism that we need mineral chemical data. 
5.4. Spectral analyses of REE-oxide powders

The majority of the pure REE-oxide powder samples display sharp absorption features in the visible, NIR and SWIR wavelength regions. The exceptions are the $\mathrm{Y}_{2} \mathrm{O}_{3}, \mathrm{CeO}_{2}, \mathrm{Gd}_{2} \mathrm{O}_{3}, \mathrm{~Tb}_{4} \mathrm{O}_{7}$ and $\mathrm{Lu}_{2} \mathrm{O}_{3}$ powders, which display smooth, broad absorptions (Fig. 9Fig. 9, the data are provided in Electronic Appendix F). For $\mathrm{Y}_{2} \mathrm{O}_{3}$ and $\mathrm{CeO}_{2}$, this is due to the absence of $4 \mathrm{f}$ electron transitions. Gadolinium only absorbs UV radiation $(<300 \mathrm{~nm})$ and Lu has a fully filled $4 \mathrm{f}$ shell, precluding 4f electron transitions (Görller-Walrand and Binnemans, 1998). The mixed oxidation state oxides, $\operatorname{Pr}_{6} \mathrm{O}_{11}$ and $\mathrm{Tb}_{4} \mathrm{O}_{7}$, do not show any sharp absorptions in the V-NIR range (Fig. 9Fig. 9). This is probably a result of their dark color, as $\mathrm{Pr}_{2} \mathrm{O}_{3}$ absorbs in the V-NIR range (Rowan et al., 1986). The $\mathrm{Nd}_{2} \mathrm{O}_{3}$ powder yielded sharp absorption features at 525, 579, 745, 799 and $869 \mathrm{~nm}$ (Fig. 10Fig. 10) identical to those reported by Rowan et al. (1986).

\subsection{Spectral analyses of reference specimens}

In order to identify cryptic alteration minerals in drill core and outcrop samples from the Nechalacho deposit and associated pegmatites, known reference samples of minerals that are detectable using V-NIR-SWIR spectroscopy were analyzed. These include the magmatic (annite, polylithionite), magmatic-hydrothermal (amphibole) and later mainstage hydrothermal mineral assemblages (phlogopite, ankerite, illite). In addition, samples of the REE-minerals, allanite-(Ce), monazite-(Ce), eudialyte and bastnäsite-(Ce) from the Nechalacho deposit and other select deposits were analyzed to determine if they can be detected using hyperspectral methods. Except for weak $\mathrm{H}_{2} \mathrm{O}$ absorptions at 1910 to $1912 \mathrm{~nm}$ in some analyses, annite from one of the deep units of the Nechalacho Layered Suite (L09-194-829.5, unit NLS-12) does not show any sharp absorptions (see Electronic Appendix E). This is due to the black color of the ironrich biotite (it is almost opaque in thin section) and its resulting low reflectivity. Phlogopitic hydrothermal biotite and Fe-Mg-rich chlorite in several reference specimens were correctly identified by the spectral assistant in the TSG software. Ankerite in sample L10-212-21.2, which has the stoichiometry $\mathrm{Ca}_{0.5} \mathrm{Fe}_{0.2} \mathrm{Mg}_{0.3} \mathrm{CO}_{3}$ (Möller and WilliamsJones, 2016b), was automatically identified by the TSG software as siderite.

\subsubsection{Amphibole}

Hydrothermal riebeckite in sample L10-251-335.7 from the Nechalacho Layered Suite (unit NLS-2; Fig. 3Fig. 3 B, Table 5Table 5) displays Fe-OH bond absorption features at 2344 and $2418 \mathrm{~nm}$ (Fig. 11Fig. 11 A), which coincide with those of published reference spectra for riebeckite (2345 and $2418 \mathrm{~nm}$; Clark et al., 1993). For arfvedsonite from 


\section{$5 \quad$ 5.5.2. Polylithionite} literature.

\subsubsection{Illite}

\subsubsection{Allanite-(Ce)}

the Strange Lake intrusion, the second absorption is shifted to $2412 \mathrm{~nm}$, probably due to the different composition. The 1414 and $1419 \mathrm{~nm}$ absorptions (Fig. 11Fig. 11 A) are caused by the hydroxyl groups in the amphibole, whereas the 1909 and 1920 features are produced by molecular $\mathrm{H}_{2} \mathrm{O}$ (Clark et al., 1990). Riebeckite in sample L10-251-335.7 was correctly identified by the TSG software, but the Strange Lake arfvedsonite was also identified as riebeckite.

Polylithionite from outcrops in the S-Zone displays a weak absorption feature at 2252 to $2253 \mathrm{~nm}$, which has a similar wavelength to the $\mathrm{Mg}-\mathrm{OH}$ absorption in biotite; it lacks other sharp absorption features (Fig. 11Fig. 11 B). This is probably due to the presence of minor Fe and Mg in the polylithionite (Černý and Trueman, 1985), which can be incorporated via solid solution in this trioctahedral mica. There are no hyperspectral data for polylithionite in the

Illite was analyzed in five reference specimens. Characteristic absorption features were observed at 2115-2118 and $2211-2215 \mathrm{~nm}$, at 2118 and $2206 \mathrm{~nm}$ in sample L10-251-292, and at $2350 \mathrm{~nm}$ (Fig. 11Fig. 11 C). The very strong $\sim 1400$ and $\sim 1900 \mathrm{~nm}$ absorptions are produced by $\mathrm{OH}^{-}$and molecular water in the illite structure, respectively (illite can incorporate molecular $\mathrm{H}_{2} \mathrm{O}$ ). All samples were automatically identified as "muscovitic illite" by the TSG software, except for sample L10-251-292, which was identified as muscovite. This is consistent with the XRD identification of these minerals as phengite and muscovite (Section 5.2, Table 4Table 4).

A number of allanite specimens from the Redpath Museum collection were analyzed. Most of them did not show any characteristic spectral reflection patterns, due probably to their opaque nature. Among these samples was a large euhedral black allanite from Minerville, New York (NS3383.1). A specimen from Tazin River (NS3386, near Uranium City, Saskatchewan) lacks REE-absorptions in the NIR range and displays Fe-OH bond absorptions at 2254 and 2341 $\mathrm{nm}$, which are characteristic of epidote (2255 and $2335 \mathrm{~nm}$ at a $5 \mathrm{~nm}$ resolution; Clark et al., 1993; Fig. $11 \mathrm{D})$. This sample is thus likely not allanite, but another epidote group member. The other two samples, from Edenville (NS3383, Orange County, New York) and Miask ("orthite", NS33852, Urals, Russia), do not absorb in this wavelength range (Fig. 11Fig. 11 D). However, they show elemental REE absorptions at 736, 798 and $863 \mathrm{~nm}$ (Miask-Br, Edenville) and 
1 at 741, 800 and $869 \mathrm{~nm}$ (Miask-Bl). Analyses of the sample from Miask detected a moderate to weak absorption at $22205 \mathrm{~nm}$, which likely reflects the presence of minor muscovite.

An sample allanite-enriched sample from the Strange Lake intrusion that is enriched in green allanite does not exhibit any epidote group-specific absorptions (Fig. 11Fig. 11 E). This may be due to their masking by absorptions of arfvedsonite. However, both spectra display sharp absorptions at 436, 755, 805 and $866 \mathrm{~nm}( \pm 1 \mathrm{~nm})$, which are due to the presence of $\mathrm{Nd}$, but are noticeably shifted from those of the pure oxide (e.g., by $\sim 10 \mathrm{~nm}$ from the $755 \mathrm{~nm}$ 7 absorption position). Two samples from the Nechalacho Layered Suite with high proportions of allanite-(Ce) 8 determined by EDS analyses also display strong Nd absorption features (Fig. 11Fig. $14 \mathrm{~F}$ ). Evidence of absorption at $92331 \mathrm{~nm}$ in sample L11-332-183.25 indicates that it contains ankerite (Fig. 11Fig. 11 F). Sample L09-160-160.4 does 10 not display any sharp absorptions in the SWIR wavelength range. In summary, the studied samples do not systematically display specific absorption features in the SWIR range that allow for the identification of allanite. 12 Although several of the allanite samples display absorption features characteristic of $\mathrm{Nd}$, we cannot rule out the possibility that these absorptions are produced by other accessorysecondary REE-bearing minerals in the specimen.

\section{5.5.5. Monazite-(Ce)}

15 The P-O bonds of phosphate minerals generally produce spectral absorption features in the mid-infrared range (Clark, 1999). Thus, the P-O bonds are not detectable using the Terraspec. Some of the higher wavelength absorptions in the spectra of the monazite-bearing samples from the Nechalacho Layered Suite are due to the presence of ankerite and biotite in the samples (Fig. 11Fig. $11 \mathrm{G}$ ). The elemental Nd absorption features, which are normally strong for 19 monazite (746, 802 and $871 \mathrm{~nm}$; Clark et al., 1993), are comparatively weak in the Nechalacho samples (Fig. 11Fig. 11

G). The absorption positions are at 741 to 749,799 to 806 and 865 to $872 \mathrm{~nm}$. Their weak intensity is likely a result of the low abundance of monazite in the samples ( $\sim 5 \mathrm{vol} . \%$ based on visual estimates from thin sections-estimates).

\section{5.5.6. Eudialyte group minerals}

Eudialyte was analyzed in order to determine if there are absorptions in the V-NIR-SWIR range that can be used to identify this mineral. Coarse-grained pink eudialyte from the Kipawa REE-deposit exhibits strong elemental $\mathrm{Nd}$ absorptions in the low NIR range, i.e., at 745, 800 and $873 \mathrm{~nm}$ (Fig. 11Fig. 11 H). The brown eudialyte from Mont 
comparison, likely because the Mont Saint-Hilaire sample is hosted in a nepheline syenite matrix. It probably does not reflect the mineral composition because eudialyte from Mont Saint-Hilaire contains similar or higher $\mathrm{Nd}$ concentrations than that from Kipawa (Schilling et al., 2011). The absorptions at $\sim 1400$ and $\sim 1900 \mathrm{~nm}$ are likely due to the presence of $\mathrm{OH}^{-}$and $\mathrm{H}_{2} \mathrm{O}$ in eudialyte (Johnsen et al., 2003). No other characteristic absorption features in the SWIR range were observed.

\subsubsection{Bastnäsite- $(\mathrm{Ce})$}

Three reference specimens of bastnäsite-(Ce) were analyzed: a sample from Mountain Pass (Redpath Museum collection), a coarse-grained sample from the T-Zone and a finer-grained sample from the Upper Zone (unit NLS-5) of the Nechalacho deposit (Fig. 12Fig. 12). The three samples display similar reflectance spectra, albeit with subtle differences. The Mountain Pass sample produces strong sharp absorptions at $742 \mathrm{~nm}, 799 \mathrm{~nm}$ (800 nm in one spot) and $864 \mathrm{~nm}$ (Fig. 12Fig. 12 A). The samples from the T-Zone and from the Upper Zone display similar absorption features at $741 \mathrm{~nm}, 798$ to $799 \mathrm{~nm}$ and at $864 \mathrm{~nm}$ (Fig. 12Fig. 12 B). The relative intensities and shapes of these absorptions match those at 745, 799 and $869 \mathrm{~nm}$ determined for Nd-oxide, but their positions are shifted by +3 to $+4 \mathrm{~nm},-1 \mathrm{~nm}$ and $+5 \mathrm{~nm}$, respectively. All bastnäsite-(Ce) spectra also contain a number of additional sharp absorption features in the NIR and SWIR range. Weak absorptions occur near 2252 - 2254 and 2318 - $2321 \mathrm{~nm}$. The absorption at $2340 \mathrm{~nm}$ (Fig. 12Fig. 12) is due to the $\mathrm{C}-\mathrm{O}$ bond in the $\mathrm{CO}_{3}^{2-}$ group of bastnäsite. These data differ significantly from those of Turner et al. (2014; 2243, 2312 and $2324 \mathrm{~nm})$ and may reflect a high sensitivity of the bastnäsite-(Ce) spectrum to differences in composition.

\subsection{Spectral analyses of drill core and outcrop samples}

Based on the petrography and the analysis of mineralogically characterized reference specimens, the alteration minerals (see Table 1 Table 1 for an overview) detectable by V-NIR-SWIR spectroscopy in the Nechalacho Layered Suite are phlogopitic biotite (Fe-OH and $\mathrm{Mg}-\mathrm{OH}$ bond absorptions), chlorite (Fe-OH, Mg-OH, Al-OH), ankerite (C-O), illite $(\mathrm{Al}-\mathrm{OH})$, riebeckite and arfvedsonite $(\mathrm{Fe}-\mathrm{OH})$, analcime $\left(\mathrm{H}_{2} \mathrm{O}\right)$ and bastnäsite- $(\mathrm{Ce})$, synchysite- $(\mathrm{Ce})$ and parisite- $(\mathrm{Ce})$ (C-O). Although allanite-(Ce) was expected to be detectable by its Al-OH bond absorption, it was not reliably identified. As none of the other REE- and Nb-minerals contain metal-OH or C-O bonds, this renders the REEfluorocarbonates the only detectable ore minerals that can be detected in the deposit. The alteration minerals in the drill 
core and outcrop samples were identified from their spectra by automatic matching using the "The Spectral Assistant" (TSA) function of the TSG Pro software, which automatically identifies the two most abundant minerals. The automated mineral identification was initially confirmed by analyzing thin section offcuts of known alteration and ore mineralogy. The automated results were also checked for plausibility and finally, the data set was simplified based enaccording to the known mineralogy of the deposit, which was determined in previous petrographic and mineral chemical studies by the current authors (Möller and Williams-Jones, 2016a; b) and Sheard et al. (2012). Thus, all detected biotite varieties were grouped as phlogopite (magmatic annite is not detectable), all carbonate minerals as ankerite (late calcite veins were avoided) and all illite, muscovite, phengite and related micas as illite. In addition, a custom library for REE-fluorocarbonates was created that includes pure and rock matrix-hosted bastnäsite-(Ce) samples from Mountain Pass, the T-Zone and the Nechalacho Layered Suite (Electronic Appendix F). The samples contain variable amounts of the other REE-fluorocarbonates, synchysite-(Ce) and parisite-(Ce), and no attempt was made to differentiate these phases from bastnäsite-(Ce). The matching was done automatically on the 700 to 900 and 2150 to $2480 \mathrm{~nm}$ wavelength ranges of the normalized hull quotient of the spectra. All automated REE-fluorocarbonate matches were confirmed manually.

\subsubsection{Drill hole L09-194}

With a depth of $1070 \mathrm{~m}, \mathrm{~L} 09-194$ is the deepest borehole drilled into the Nechalacho Layered Suite to date and provides a vertical profile through the intrusion (Fig. 13). Erosion removed units NLS-1, NLS-2 and the top of NLS-3. Two indicators of alteration intensity are shown in Figure 13, the whole rock $\mathrm{MgO}$ concentration and the magnetic susceptibility. Magnesium was introduced exclusively hydrothermally by hydrothermal fluids into the Nechalacho Layered Suite and incorporated in the hydrothermal Mg-bearing minerals, biotite, ankerite, chlorite and illite. Magnetite formed exclusively hydrothermally by hydrothermal processes and is the only magnetic mineral in the rock suite (Möller and Williams-Jones, 2016a). The whole rock compositions were analyzed continuously from the top of the drill hole to a depth of $299 \mathrm{~m}$; below this, $1 \mathrm{~m}$ long samples were taken every $10 \mathrm{~m}$. The magnetic susceptibility was measured in $1 \mathrm{~m}$ intervals. The alteration is most intense in the upper part of the Nechalacho Layered Suite, in particular in the eudialyte-bearing units NLS-4 and NLS-6, but also affected two pervasive alteration zones deeper in the intrusion (Fig. 13). Magnetite abundance and $\mathrm{MgO}$ concentration are correlated on the large scale, but also vary independently, e.g., $\mathrm{MgO}$ enrichment is moderate to strong in unit NLS-8, whereas magnetite is a minor phase (Fig. 
13). This localized decoupling of $\mathrm{MgO}$ and magnetite abundance is a result of primary modal variations in the rocks, i.e., varying abundances of aegirine, the precursor mineral for hydrothermal magnetite, and K-feldspar, the precursor for hydrothermal biotite and chlorite.

Spectral data were collected in $1 \mathrm{~m}$ intervals for the top $300 \mathrm{~m}$ of the drill hole, every half meter for the Basal Zone and every 5 to $10 \mathrm{~m}$ in the lower part of the drill hole. Based on automated mineral identification from the spectra, hydrothermal chlorite, ankerite, illite and biotite are most abundant in the upper $260 \mathrm{~m}$ (Fig. 13). As magmatic annite cannot be detected by spectral analysis; the biotite is exclusively the hydrothermal Mg-enriched variety. Chlorite and biotite are negatively correlated and ankerite abundance varies independently of these two minerals. Illite is most abundant in unit NLS-8, which contained a high proportion of magmatic sodalite, the only precursor mineral for illite (Fig. 13). Hydrothermal illite and biotite are also present in the two lower alteration zones (Fig. 13). In the deeper units that were less affected by Mg-metasomatism, magmatic-hydrothermal deuteric analcime (formed at the expense of magmatic sodalite and nepheline prior to the main-stage alteration) is the most abundant hydrothermal alteration mineral (Fig. 13). Analcime was initially automatically identifiedmisidentified as palygorskite (a rare phyllosilicate with the formula $\left[\mathrm{Mg}_{2} \mathrm{Al}_{2} \underline{\mathrm{Si}}_{4} \underline{\mathrm{O}}_{10}[\mathrm{OH}] \cdot 4 \mathrm{H}_{2} \mathrm{O}\right.$ ) by the TSA, due tikely to the similarly strong $\mathrm{H}_{2} \mathrm{O}$ and $-\mathrm{OH}$-absorption features near 1415 to 1420 and 1910 to $1930 \mathrm{~nm}$ of the two minerals (cf., analcime formula in Table 2), but manual analysis indicated that the spectra match analcime. Accordingly, a custom automatic matching routine for analcime reference spectra from the USGS library (Clark et al., 2007) was used. Based on the spectral data, the biotite + illite alteration and analcime alteration types are mutually exclusive, consistent with the late hydrothermal overprint of the earlier analcime. Bastnäsite-(Ce) is clearly correlated with the main-stage alteration in the shallow and deeper alteration zones (Fig. 13).

\subsubsection{Drill hole L10-232}

The top of the Nechalacho Layered Suite was intersected by drill hole L10-232 (Fig. 14). The MgO concentration is high in the units that were enriched in magmatic sodalite; this mineral was replaced completely by hydrothermal illite (units NLS-1 and NLS-7, Fig. 14). In addition, the two eudialyte syenite layers (Upper and Basal Zones) were susceptible to hydrothermal Mg-metasomatism and, as a result of the high primary aegirine content, also to magnetite replacement (Fig. 14). Despite a strong Mg-enrichment, only minor biotite was detected in unit NLS-5. Chlorite is 
most abundant in units NLS-2 and NLS-4, and biotite in units NLS-4 to NLS-7. There is also accessory hydrothermal 2 riebeckite.

\subsubsection{Hydrothermal alteration mineralogy in cross section $A-A^{\prime}$}

Visible-NIR-SWIR spectra were collected for seven drill holes along cross section A-A', (Figs. 2, 15). The measurements were performed systematically every two meters downhole, except for drill hole L09-194, which was analyzed every meter and every $0.5 \mathrm{~m}$ in the Basal Zone, and drill hole L11-347, for which only a limited number of representative samples of the Basal Zone were available. Select additional analyses were done for the Basal Zone of drill hole L09-160. The analytical data are included in Electronic Appendix F. The mineral occurrences were contoured manually along the cross section, i.e., zones containing the same mineral were drawn by hand. There is no systematic inward zoning of the alteration minerals (Fig. 15Fig. 15 A). The distribution of ankerite and chlorite is largely independent of the nature of the primary precursor magmatic lithologicaligneous units (Fig. 15Fig. $15 \mathrm{~A})$. In contrast, a strong host rock control is evident for the REE-fluorocarbonates, with most occurrences being in the Basal and Upper Zones (Fig. 15Fig. 15 A). There are, however, hydrothermal occurrences of the REE-fluorocarbonates outside the magmatic REE-mineralized layers (e.g., at the top of drill hole L11-374). The distribution of phlogopite indicates both a host rock and fluid control. For clarity, illite is not shown in this cross section since its occurrence, with rare exception, is restricted to the Roof Sodalite Syenite (Fig. 15Fig. 15 B).

\subsubsection{Alteration mineralogy of the Basal Zone}

The distribution of the hydrothermal alteration minerals in the eudialyte cumulates and eudialyte syenites of the Basal Zone is highly variable (Fig. 16Fig. 16). In particular, ankerite is rare in drill hole L10-232, whereas this mineral is abundant in the domains of the Basal Zone intersected by the other drill holes, and together with quartz (based on petrography) forms the main hydrothermal alteration mineral assemblage in drill hole L12-426 (Fig. 16Fig. 16). This agrees with petrographic observations (Möller and Williams-Jones, 2017, in revision). Phlogopite shows similarly strong variations; it is most abundant in drill hole L12-443. Abundances of cChlorite and illite are overall of minor abundance. Some domains contain little ankerite and phlogopite (the main host minerals for $\mathrm{Mg}$ ), e.g., at the top of drill holes L10-232 and L12-443. Nonetheless, the whole rock geochemical data indicate strong hydrothermal Mg 
enrichments in these zones. This likely reflects the nature of the point analyses, i.e., the spectral measurement is not representative of the entire sample interval.

Drill hole L12-426 is located in the least-altered part of the Basal Zone (Möller and Williams-Jones, 2017, in revision); it intersected only small amounts-minor amounts of hydrothermal magnetite (Fig. 16Fig. 16). The spectral data, in agreement with petrographic observations, indicate only small proportions of hydrothermal phlogopite (Fig. 16Fig. 16). In this case, the abundance of ankerite, the main host for $\mathrm{Mg}$, correlates directly with the whole rock $\mathrm{MgO}$ contents. The abundance of magnetite is a function of both the content of primary aegirine in the rocks and alteration intensity. Magnetite and phlogopite commonly occur together but both minerals also occur independently of each other. Locally, magnetite and ankerite are present separately, but more commonly occur together. The occurrence of REE-fluorocarbonates correlates loosely with the presence of ankerite but is independent of the abundance of phlogopite and magnetite. For example, core from drill hole L10-232 contains only minor proportions of REEfluorocarbonates and ankerite. The REE-fluorocarbonates occur at different stratigraphic levels in the Basal Zone and are not directly related to the bulk rock REE concentration. In the REE-rich lowest part of the Basal Zone of drill holes L10-232 and L12-443, REE-fluorocarbonates were not detected, indicating that other minerals are the main host for the REE in these domains.

\subsubsection{Quantitative estimates of $N d$ content from the $741 \mathrm{~nm}$ absorption feature}

Although La and Ce are the most abundant REE in the mineralized rock units of the Nechalacho Layered Suite, their spectra do not display sharp absorptions sharp enough to that allow quantification (Fig. 9Fig. 9). In contrast, the spectra of pure REE-oxides and reference specimens of REE-minerals indicate that the $741 \mathrm{~nm}$ elemental absorption feature of $\mathrm{Nd}$ is suitable for a quantitative treatment (Figs. 9 to 11). The relative absorption depth, $\zeta$, of the $741 \mathrm{~nm}$ feature of Nd was calculated with the TSG Pro software by dividing the minimum value at $741 \pm 5 \mathrm{~nm}$ by the hull quotient with local continuum removal activated. Empirical tests showed that the $\sim 799 \mathrm{~nm}$ absorption of $\mathrm{Nd}$ in the rock matrix of the Nechalacho Layered Suite is weaker $\left(\zeta_{799} \mathrm{~nm}=0.5706 \cdot \zeta_{741 \mathrm{~nm}}+7 \cdot 10^{-5}\right.$ for 0 to $300 \mathrm{~m}$ of drill hole L09-194), whereas the $\sim 864 \mathrm{~nm}$ absorption is approximately the same as that at $\sim 741 \mathrm{~nm}\left(\zeta_{864 \mathrm{~nm}}=1.0706 \cdot \zeta_{741 \mathrm{~nm}}+5 \cdot 10^{-5}\right)$. All three absorption features, however, are perfectly correlated (the Pearson correlation coefficient $\mathrm{r}$ ranges from 0.98 to 0.99 ). In the strip logs of Figure 17 for drill holes L09-194 and L10-232, $\zeta_{741} \mathrm{~nm}$ is compared to the REE concentrations measured by solution ICP-MS. The Nd content correlates well with the total REE and heavy REE concentrations and 
$\zeta_{741 \mathrm{~nm}}$ is clearly stronger in the Nd-enriched layers (Fig. 17Fig. 17). The Basal Zone is particularly well-delineated by 2 the $741 \mathrm{~nm}$ absorption feature (Fig. 17Fig. 17). To evaluate the correlation between spectral data and assays for Nd 3 quantitatively, the data from four drill holes were analyzed (Fig. 18). Each spectral analysis was automatically assigned 4 the corresponding bulk rock Nd assay value using a custom Excel VBA Macro script. The Pearson correlation 5 coefficient, $\mathrm{r}$, between the $\mathrm{Nd}$ concentration and the base 10 llogarithm of the absorption depth ranges between 0.49 6 and 0.62 (Fig. 18). For the combined data from the four drill holes, $r$ is 0.58 (Fig. 19). This indicates scattering of the 7 data, but also a statistically significant correlation.

\section{$8 \quad$ 5.6.6. Outcrop samples}

9 Outcrop samples were analyzed to evaluate the surface exploration applicability of V-NIR-SWIR spectroscopy in the 10 REE deposit environment. A total of 224 spectral analyses were performed, with several measurements on each outcrop sample to account for the mineralogical variability. Similar spectral data within individual samples were then 12 averaged to a total of 64 groups. Limited surface samples were available owing to the paucity of outcrops. Hence, the 13 topmost analyses from 11 drill holes were added to the outcrop data set. Figure 20 illustrates the relative absorption 14 depth of the $741 \mathrm{~nm}$ feature for these samples. There is considerable small-scale variation for samples in the same 15 location, but the REE-enrichment of the Upper Zone of the Nechalacho Layered Suite is was correctly identified (Fig. 16 20). The REE-mineralization of the South T-, R- and S-zones is-was also identified from the $741 \mathrm{~nm}$ absorption 17 parameter. Rare earth element-fluorocarbonates were identified in seven of the outcrop samples. The hydrothermal 18 alteration mineralogy in the outcrop samples from the Nechalacho Layered Suite, the Thor Lake Syenite and the 19 pegmatites is similar and eonsists limited mainly of to chlorite and ankerite, and rare biotite. Illite is restricted to the 20 altered sodalite-enriched units of the Nechalacho Layered Suite.

\section{Discussion}

\subsection{Spatial distribution of the alteration minerals}

The relatively complex alteration of the Nechalacho Layered Suite differs in many respects from that of replacementtype precious and base metal deposits. To a large degree, the complexity is the result of the primary mineralogical variability of the protolith, but is also due also to the overprint of the orthomagmatic cumulate-style mineralization by several hydrothermal events. As opposed to one alteration mineral changing composition (e.g., muscovite, Harraden et 
1 al., 2013), the identity of multiple secondary minerals in the Nechalacho Layered Suite varies as a function of 2 precursor mineralogy. This is most clearly recorded by the replacement of magmatic sodalite by hydrothermal illite 3 (Fig. 14) and the magnetite replacement of aegirine by magnetite. In addition, the hyperspectral data allow for the 4 spatial contouring of cryptic hydrothermal mineral zoning (biotite, chlorite, ankerite) that varies independently of the 5 precursor mineralogy (Fig. 15Fig. 15). There are limitations to the hyperspectral identification of the alteration 6 minerals. For example, no Mg-bearing minerals were identified in some zones that contain have high whole rock $\mathrm{Mg}$ 7 concentrations (e.g., unit NLS-5 in drill hole L10-232, Fig. 14; top of the Basal Zone in L12-443, Fig. 16Fig. 16). This 8 could be due to spectral masking by opaque magnetite or a random effect of the punctual nature of the spectral 9 measurements, leading to an absence of biotite, chlorite or ankerite in the analytical window.

to its occurrence in veins, interstices between crystals and as disseminations (as opposed to being a replacement mineral). Consistent with petrographic observations of its presence in veins, the distribution of chlorite is also decoupled from the host rock. Chlorite is stable relative to phlogopite at lower temperature eombined and with-lower $\mathrm{pH}$ and/or $a \mathrm{~K}^{+}$in the fluid (Möller and Williams-Jones, 2017, in revision). Indeed, zones with a core of biotite mantled

by chlorite alteration-were observed locally, possibly indicating thermal zoning (e.g., in the lower part of drill hole L09-194; Fig. 15Fig. 15). More commonly, however, there is no systematic zoning involving biotite and chlorite (Fig. 15Fig. 15). On the detailed scale of the studied drill cores and cross section, none of the alteration minerals systematically act as vectors towards the zones of REE and Nb mineralization (Figs. 13, 14, 15). In order to solidify the latter conclusion, it would be useful to acquire a more extensive, intrusion-wide hyperspectral data set and model the distribution of the alteration minerals in 3-D. On a larger scale, it is noteworthy that hydrothermal minerals similar to those are at the top of the intrusion (phlogopite, magnetite) are also present at depth, but the alteration is less intense (Fig. 13). This is likely due to the lower resistance to alteration of the upper eudialyte-rich units. Ankerite and chlorite, however, are only observed at the top of the intrusion (Fig. 13) and in the outcrops and altered pegmatites. Whereas the distribution of ankerite, at least partially, was probably controlled magmatically (see below), a combination of cooling hydrothermal fluids and lower $\mathrm{pH}$ due to weaker rock-buffering in the intensely altered upper units likely explain the chlorite enrichment at the top of the Nechalacho Layered Suite and surrounding alteration zones. 
There is a mutually exclusive relationship between the magmatic-hydrothermal mineral analcime and the main2 stage alteration minerals (biotite, chlorite, ankerite, illite, REE-fluorocarbonates; Fig. 13). This can be explained by the 3 later timing (1871 to $1835 \mathrm{Ma}$; Möller and Williams-Jones, 2016b) of the main-stage alteration, which overprinted the 4 magmatic-hydrothermal stage pervasively along diffuse zones during a regional event. The regional nature of the 5 overprint may also explain the chaotic small-scale distribution of the alteration in the Nechalacho Layered Suite. 6 Similarly to analcime, rare magmatic-hydrothermal amphibole (riebeckite and arfvedsonite, which formed from 7 alkaline fluids) was probably overprinted by the main-stage alteration fluids. Hydrothermal carbonates initially 8 precipitated from magmatic-hydrothermal carbonic fluids in the cupola of the intrusion and surrounding pegmatites

9 (Möller and Williams-Jones, 2016b), thereby explaining the ankerite-enrichment at the top. Ankerite, however, was also stable during the later main-stage alteration (Möller and Williams-Jones, 2017, in revision), which probably remobilized magmatic-hydrothermal carbonates. With rare exception, the correlation of the $\mathrm{MgO}$ concentration and magnetite abundance (tracked by magnetic susceptibility) confirms that biotite, chlorite and magnetite are part of the same hydrothermal mineral assemblage (Figs. 13, 14, 16). The magnetite replacement of aegirine indicates the

\section{presence of reducing alteration fluids relative to the magmatic conditions in the Nechalacho Layered Suite and to other} oxidizing hydrothermal environments, in which hematite or goethite would form (see Möller and Williams-Jones, 2017, in revision, for a more detailed discussion of the redox conditions). The semi-quantitative mass-balance for unit NLS-1 (Roof Sodalite Syenite, Fig. 7) confirms that Mg was introduced hydrothermally during the main-stage alteration and was accompanied by a substantial loss of $\mathrm{Na}$ (Möller and Williams-Jones, 2016a; 2017, in revision). The X-ray diffraction analysis of illite (celadonite or aluminoceladonite) indicates that it formed at a relatively high temperature $\left(>300^{\circ} \mathrm{C}\right)$, consistent with previous estimates for alteration temperatures in the Nechalacho Layered Suite ( $\sim 300{ }^{\circ} \mathrm{C}$; Möller and Williams-Jones, 2016b). In addition to the primary magmatic precursor mineralogy and fluid flow, compositional variability of the main-stage alteration fluid was likely a third important control. This is indicated by the presence of zones which contain only magnetite (i.e., Mg-bearing minerals are absent, due probably to the presence of Mg-depleted fluid; Fig. 13) and zones which dominantly contain ankerite (likely owing to the presence of $\mathrm{CO}_{2}$-rich fluid; Fig. 16Fig. $16 \mathrm{C}$ ). As we have not attempted to quantify the $\mathrm{Mg} / \mathrm{Fe}$ ratios of any of the alteration minerals, this would represent an opportunity for potential follow-up hyperspectral studies. 


\subsection{Distribution of the REE-fluorocarbonates}

Bastnäsite-(Ce), synchysite-(Ce) and parisite-(Ce) are the only REE-ore minerals in the Nechalacho Deposit identifiable by V-NIR-SWIR spectroscopic methods. The REE-fluorocarbonates occur preferentially in the altered magmatic eudialyte cumulate layers (Figs. 13, 14, 15), but some domains in the Basal Zone contain only minor proportions of REE-fluorocarbonates (Fig. 16Fig. 16). This indicates that there was a strong host rock control on their hydrothermal formation. The REE-fluorocarbonates are closely associated with the ankerite \pm chlorite alteration (Fig. 15Fig. $15 \mathrm{~A}$ ), in agreement with petrographic observations. In addition, hydrothermal remobilization of light REE and their re-deposition as REE-fluorocarbonates in vein zones associated with ankerite \pm chlorite alteration took place locally (e.g., at the top of drill hole L11-347; Fig. 15Fig. 15). These observations show that the REE fluorocarbonates formed in response to interaction of Mg-bearing, carbonic-hydrothermal fluids with the eudialyte syenites. This explains the abundance of REE-fluorocarbonates, minerals that are more commonly hosted in REE-rich carbonatites, in the Nechalacho deposit. The localized leaching and redeposition of light REE in vein zones took place during the waning stages of the main-stage alteration. The delineation of REE-fluorocarbonate zones in the Nechalacho deposit is useful for metallurgical eonsiderationsreasons; their identification in outcrop may be valuable for future exploration efferts.

\subsection{Rare earth element grade estimation and ore zone identification using hyperspectral data}

Despite the fact that only a limited number of REE-minerals can be identified in the Nechalacho deposit (the REEfluorocarbonates), the REE can be detected by their hyperspectral absorption features, independent of the mineral. The heavy REE are generally not sufficiently abundant to allow detection. Cerium would be the ideal representative of the REE, because the most abundant REE-minerals are Ce-dominated (e.g., bastnäsite-[Ce], monazite-[Ce], allanite-[Ce]). However, as noted earlier, Ce lacks sharp spectral absorption features in the V-NIR-SWIR wavelength range (Fig. 9Fig. 9). Owing to a LREE enrichment of the rocks of the Nechalacho Layered Suite (Möller and Williams-Jones, 2016a; 2017, in revision), and to the Oddo-Harkins effect and the removal of Eu by fractionation, $\mathrm{Nd}$ is the most abundant REE after Ce. Based on the bulk rock data of Möller and Williams-Jones (2016a) for the Nechalacho Layered Suite, the Pearson correlation coefficient for $\mathrm{Nd}$ with the sum of REE is 0.98 and $\mathrm{r}_{\mathrm{Nd}, \mathrm{Nb}}$ is 0.92 . This correlation and a characteristic and readily quantifiable absorption feature $(741 \mathrm{~nm})$ make $\mathrm{Nd}$ the ideal representative of the REE and a proxy element for $\mathrm{Nb}$ in the deposit. The identification of the $741 \mathrm{~nm}$ absorption feature of $\mathrm{Nd}$ in reference specimens 
of bastnäsite-(Ce), monazite-(Ce), allanite-(Ce) and eudialyte from different localities (Figs. 11, 12) demonstrates that

this method can be used for a wide range of REE-minerals and REE deposits. The elemental absorption of Nd at $\sim 741$ $\mathrm{nm}$ is only weakly affected by the crystallographic bonding environment (Figs. 10,11,12), owing to the fact that only the two outer valence electron are engaged in bonding, whereas the absorptions in the visible spectrum are due to interaction of photons with their $4 \mathrm{f}$ electrons. No other REE and no other minerals from the deposit have features that overlap the $741 \mathrm{~nm}$ absorption. Therefore, this feature facilitates the rapid ( $2.5 \mathrm{~s})$ field identification of REE-minerals as a drill core logging aid, even without any post-processing of the spectral data. This is a significantly faster method than portable XRF analysis ( $\sim 30$ to $60 \mathrm{~s}$ for each analysis including select REE, although this is a quantitative method). The main limitations of this method of REE detection are that the $741 \mathrm{~nm}$ absorption feature is masked in opaque minerals, e.g., some varieties of allanite (Fig. 11Fig. 11 D), and cannot be detected if the REE-mineral concentration is low (Fig. 11Fig. $11 \mathrm{G}$ ). Thus, the detection of REE via NIR spectral features would not be a suitable method for mineral deposits in which the REE are largely hosted in opaque minerals.

Arguably, the most significant finding of this study is that the correlation between the relative depth of the 741 $\mathrm{nm}$ spectral absorption of $\mathrm{Nd}$ and the whole rock $\mathrm{Nd}$ assay values is both qualitatively (Fig. 17Fig. 17) and quantitatively significant (Figs. 18, 19) and allows both the Upper and Basal Zones, i.e., the principal layers of REE$\mathrm{Nb}$ enrichment in the Nechalacho deposit, to be reliably delineated. The main effect that reduces the correlation coefficient is rooted in the nature of the analyses: the spectral data are collected as point measurements and the assay values are interval data. This implies that the spectral data can be representative for relatively homogeneous (e.g., finegrained disseminated or massive) deposits, but will be problematic for cumulate or vein deposits, unless the sample density is sufficient. In the Nechalacho deposit, a measurement interval of $0.5 \mathrm{~m}$ allows the REE-mineralized zones to be reliably identified. In addition, it has to be considered that even the host rocks to the REE ore zones in the Nechalacho Layered Suite contain patchy REE mineral occurrences; point measurements can thus also provide a false positive bias (e.g., in the lower part of both drill holes in Fig. 17Fig. 17). The issue of point versus bulk measurements is fully exposed in the variable $\mathrm{Nd}$ spectral absorption data recorded by the outcrop samples around Thor Lake (variable circle sizes at individual locations in Fig. 20). This shows that there is considerable small scale variability in the abundance of REE-minerals, in agreement with the observation that the outcrop samples contain patchy and veinstyle mineralization. For drill core, the challenge of potentially biased punctual hyperspectral data can be overcome by 
using commercial whole drill core scanning techniques such as Corescan, TerraCore, ${ }_{\text {Hylogger, }}$ or SisuROCK or ProSpecTIR (e.g., Huntington et al., 2006; Kruse et al., 2012; Speta et al., 2013; Schodlok et al., 2016). These 3 techniques are, however, are significantly less portable and associated with markedly higher costsa lot more costly.

We conclude that the automated analysis of the spectral absorptions of Nd provides a fast and cost-effective field method for the qualitative identification of REE-minerals and the systematic quantitative delineation of REE-Nb mining environments. Although remote sensing using NASA's Advanced Spaceborne Thermal Emission and Reflection Radiometer (ASTER) or Airborne Visible / Infrared Imaging Spectrometer (AVIRIS) would be of limited lakes), the 741 and $864 \mathrm{~nm}$ absorptions of $\mathrm{Nd}$ are spectral features that would allow the remote identification of REE deposits in regions with greater outcrop exposure.

\section{7. Conclusions}

13 The spatial distribution of the secondary mineralogy of the magmatic-hydrothermal and later main-stage alteration of 14 the Nechalacho Layered Suite was tracked successfully by hyperspectral field analyses conducted in the context of a 15 detailed mineralogical and geochemical framework. This distribution includes mutually exclusive zones of magmatic16 hydrothermal analcime replacement and later biotite-ankerite-chlorite alteration. The latter, main-stage alteration, was 17 associated with significant mass gains of $\mathrm{Mg}$ and loss of $\mathrm{Na}$ at temperatures greater than or equal to $300{ }^{\circ} \mathrm{C}$. The 18 primary precursor lithology, fluid pathways and fluid composition exerted strong controls on the alteration mineralogy.

19 At the extreme ends of the spectrum, carbonate metasomatism was intense and fluid-controlled, whereas illite indicated by zones of Mg-metasomatism (biotitization, chloritization) and co-genetic, but spatially distinct zones of magnetitization. In contrast to the deep parts of the intrusion, the upper, REE-mineralized top is conspicuously enriched in hydrothermal chlorite and ankerite, but in detail the distribution of these minerals is chaotic and does not allow their use as pathfinders towards-for mineralization. This study of the Nechalacho rare metal deposit demonstrates that V-NIR-SWIR spectroscopy can be used to identify REE-fluorocarbonates and reliably delineate REE ore zones using either a qualitative or quantitative treatment of the data. The distribution of the REE-fluorocarbonates in the Nechalacho deposit was mainly controlled by the host rocks, i.e., by the presence of precursor eudialyte as the source 
for in situ reconstitution of the REE, but also by the localized hydrothermal remobilization of light REE and their redistribution in vein zones containing REE-fluorocarbonates associated with ankerite \pm chlorite alteration. Analysis of pure REE-oxide powders and reference mineral specimens confirmed that neodymium can be reliably identified by its 741, 798 and $864 \mathrm{~nm}$ absorptions, independently of the nature of the host REE-mineral. By systematically comparing drill hole assay data to software-processed and quantified elemental spectral $\mathrm{Nd}$ absorptions (741 nm), we have demonstrated a strong correlation between assay and spectral data. The 741 and $864 \mathrm{~nm}$ Nd absorptions can be used as a direct proxy for REE-mineralization in drill core and outcrop. Analyses of reference specimens showed that the results of this study are transferable to other mineralogically different REE. In addition to its application in exploration,

V-NIR-SWIR spectroscopy would also be suitable for cost-effective grade control in mine settings.

\section{Acknowledgements}

This project was funded by Collaborative Research and Developments grants from Avalon Advanced Materials Inc. and the Natural Sciences and Engineering Research Council of Canada. William Mercer, J.C. Pedersen and R. O'Keefe provided access to the drill core repository and logistical field support, and engaged in helpful discussions. Peter Tarassoff (Honorary Curator, Redpath Museum, McGill University) supplied reference mineral specimens for this study. Michel Preta (Université du Québec à Montréal) performed the XRD analyses. The Terraspec 4 High Res mineral analyzer was provided by ASD Inc. (Panalytical) through the 2014 Students in Mining Program. Tom Ulrich and Christopher Butz are acknowledged for their support. A research license of The Spectral Geologist software (developed by CSIRO) was provided by Ausspec International. Finally, the manuscript benefitted significantly from $\underline{\text { the insightful and helpful comments of an anonymous referee, }}$

\section{References}

Avalon Rare Metals Inc., 2013. News Release 13-07 - Avalon Reports on Summer Work Program at the Nechalacho Rare Earth Elements Project and Provides Mineral Resource Update, Toronto, 5 pp.

Berman, M., Bischof, L., Huntington, J., 1999. Algorithms and software for the automated identification of minerals using field spectra or hyperspectral imagery, Proceedings of the 13th International Conference on Applied Geologic Remote Sensing, Vancouver, volume 1. Environmental Research Institute of Michigan, Ann Arbor, pp. 222-232.

Berman, M. et al., 2011. An unmixing algorithm based on a large library of shortwave infrared spectra (Report Number EP117468). CSIRO.

Černý, P., Trueman, D.L., 1985. Polylithionite from the rare-metal deposits of the Blachford Lake alkaline complex, N.W.T., Canada. Am. Mineral., 70: 1127-1134.

Clark, R.N., 1999. Spectroscopy of Rocks and Minerals, and Principles of Spectroscopy. In: Rencz, A.N. (Ed.), Manual of Remote Sensing. John Wiley and Sons, New York. 
Clark, R.N., King, T.V.V., Klejwa, M., Swayze, G.A., Vergo, N., 1990. High spectral resolution reflectance spectroscopy of minerals. Journal of Geophysical Research: Solid Earth, 95(B8): 12653-12680.

Clark, R.N., Swayze, G.A., Gallagher, A.J., King, T.V.V., Calvin, W.M., 1993. The U. S. Geological Survey, Digital Spectral Library: Version 1: 0.2 to 3.0 microns, U.S. Geological Survey Open File Report 93-592.

Clark, R.N. et al., 2007. USGS Digital Spectral Library splib06a, U.S. Geological Survey.

CSIRO, 2013. The Spectral Geologist Version 7 User Manual, Sydney.

Deer, W.A., Howie, R.A., Zussman, J., 1992. The rock-forming minerals. Pearson Education Limited, Harlow, 549 pp.

Dieke, G.H., Crosswhite, H.M., 1963. The spectra of the doubly and triply ionized rare earths. Appl. Opt., 2(7): 675686.

Duba, D., Williams-Jones, A.E., 1983. The application of illite crystallinity, organic matter reflectance, and isotopic techniques to mineral exploration: a case study in southwestern Gaspé, Quebec. Econ. Geol., 78: 1350-1363.

Görller-Walrand, C., Binnemans, K., 1998. Spectral intensities of f-f transitions. In: Gschneidner, K.A., Jr., Eyring, L. (Eds.), Handbook on the Physics and Chemistry of Rare Earths, pp. 101-264.

Harraden, C.L., Mcnulty, B.A., Gregory, M.J., Lang, J.R., 2013. Shortwave infrared spectral analysis of hydrothermal alteration associated with the pebble porphyry Copper-Gold-Molybdenum Deposit, Iliamna, Alaska. Econ. Geol., 108(3): 483-494.

Herrmann, W. et al., 2001. Short wavelength infrared (SWIR) spectral analysis of hydrothermal alteration zones associated with base metal sulfide deposits at Rosebery and Western Tharsis, Tasmania, and Highway-Reward, Queensland. Econ. Geol., 96(5): 939-955.

Hunt, G.R., Ashley, R.P., 1979. Spectra of altered rocks in the visible and near infrared. Econ. Geol., 74: $1613-1629$.

Huntington, J.F. et al., 2006. Automated mineralogical core logging at the Emmie Bluff iron oxide copper-gold prospect. MESA Journal, 41: 38-44.

International Mineralogical Association, 2017. The new IMA list of minerals - a work in progress - updated: March 2017 http://nrmima.nrm.se//IMA_Master_List_(2017-03).pdf, pp. 206.

Ji, J., Browne, P.R.L., 2000. Relationship between illite crystallinity and temperature in active geothermal systems of New Zealand. Clays and Clay Minerals, 48(1): 139-144.

Johnsen, O. et al., 2003. The nomenclature of eudialyte-group minerals. The Canadian Mineralogist, $41(3): 785-794$.

Jones, S., Herrmann, W., Gemmell, J.B., 2005. Short wavelength infrared spectral characteristics of the HW horizon: implications for exploration in the Myra Falls volcanic-hosted massive sulfide camp, Vancouver Island, British Columbia, Canada. Econ. Geol., 100(2): 273-294.

Kruse, F.A. et al., 2012. Mapping alteration minerals at prospect, outcrop and drill core scales using imaging spectrometry. International journal of remote sensing, 33(6): 1780-1798.

Kübler, B., Jaboyedoff, M., 2000. Illite crystallinity. Comptes Rendus de l'Académie des Sciences Paris / Earth and Planetary Sciences, 331: 75-89.

McGill, I., 2000. Rare Earth Elements. In: Bellussi, G. et al. (Eds.), Ullmann's Encyclopedia of Industrial Chemistry. Wiley-VCH, Weinheim, Germany, pp. 183-228.

Meunier, A., Velde, B., 2004. Illite - Origins, evolution and metamorphism. Springer, Berlin Heidelberg, 286 pp.

Möller, V., Williams-Jones, A.E., 2016a. Petrogenesis of the Nechalacho Layered Suite, Canada: Magmatic evolution of a REE-Nb-rich nepheline syenite intrusion. J. Petrol., 57(2): 229-276.

Möller, V., Williams-Jones, A.E., 2016b. Stable and radiogenic isotope constraints on the magmatic and hydrothermal evolution of the Nechalacho Layered Suite, northwest Canada. Chem. Geol., 440: 248-274.

Möller, V., Williams-Jones, A.E., 2017, in revision. Magmatic and hydrothermal controls on the mineralogy of the Basal Zone, Nechalacho REE-Nb-Zr deposit, Canada. Econ. Geol.

Rieder, M. et al., 1998. Nomenclature of the micas. Clays and Clay Minerals, 46(5): 586-595.

Rowan, L.C., Kingston, M.J., Crowley, J.K., 1986. Spectral reflectance of carbonatites and related alkalic igneous rocks: selected samples from four North American localities. Econ. Geol., 81(4): 857-871.

Schilling, J. et al., 2011. The compositional variability of eudialyte-group minerals. Mineral. Mag., 75(1): 87-115.

Schodlok, M. et al., 2016. HyLogger-3, A visible to shortwave and thermal infrared reflectance spectrometer system for drill core logging: Functional description. Australian Journal of Earth Sciences, 63(8): 929-940.

Sheard, E.R., Williams-Jones, A.E., Heiligmann, M., Pederson, C., Trueman, D.L., 2012. Controls on the concentration of zirconium, niobium, and the rare earth elements in the Thor Lake rare metal deposit, Northwest Territories, Canada. Econ. Geol., 107(1): 81-104.

Simandl, G.J., Fajber, R., Paradis, S., 2014a. Portable X-ray fluorescence in the assessment of rare earth elementenriched sedimentary phosphate deposits. Geochemistry: Exploration, Environment, Analysis, 14: 161-169. 
Simandl, G.J. et al., 2014b. Applicability of handheld X-Ray fluorescence spectrometry in the exploration and development of carbonatite-related niobium deposits: a case study of the Aley Carbonatite, British Columbia, Canada. Geochemistry: Exploration, Environment, Analysis, 14: 211-221.

Speta, M., Rivard, B., Feng, J., Lipsett, M., Gingras, M., 2013. Hyperspectral imaging for the characterization of athabasca oil sands drill core, Geoscience and Remote Sensing Symposium (IGARSS), 2013 IEEE International. IEEE, pp. 2184-2187.

Timofeev, A., Williams-Jones, A., 2015. The Origin of Niobium and Tantalum Mineralization in the Nechalacho REE Deposit, NWT, Canada. Econ. Geol., 110(7): 1719-1735.

Tindle, A., Webb, P., 1994. PROBE-AMPH - a spreadsheet program to classify microprobe-derived amphibole analyses. Computers \& Geosciences, 20(7): 1201-1228.

Trueman, D.L., Pedersen, J.C., de St Jorre, L., Smith, D.G.W., 1988. The Thor Lake rare-metal deposits, Northwest Territories. In: Taylor, R.P., Strong, D.F. (Editors), Recent Advances in the Geology of Granite-Related Mineral Deposits, Proceedings of the CIM conference on Granite-Related mineral deposits, September 1985. Special volume. Canadian Institute of Mining and Metallurgy, Montreal, pp. 280-290.

Turner, D.J., Rivard, B., Groat, L.A., 2014. Visible and short-wave infrared reflectance spectroscopy of REE fluorocarbonates. Am. Mineral., 99(7): 1335-1346.

White, W.B., 1967. Diffuse-reflectance spectra of rare-earth oxides. Appl. Spectrosc., 21(3): 167-171. 


\section{Tables}

2 Table 1: The main hydrothermal alteration minerals and their magmatic precursors. $\underline{p \text { Primary magmatic mineral }}$ alteration mineral $(\underline{s})^{2}$

\begin{tabular}{|c|c|}
\hline$p$ Primary magmatic mineral & alteration mineral $(\underline{\mathrm{s}})^{\mathrm{a}}$ \\
\hline K-feldspar & phlogopite and/or chlorite \\
\hline albite & stable \\
\hline annite & phlogopite and/or chlorite \\
\hline \multirow[t]{3}{*}{ aegirine } & (1) riebeckite \\
\hline & (2) magnetite + quartz \\
\hline & (3) hematite \\
\hline \multirow[t]{2}{*}{ sodalite } & (1) analcime \pm cancrinite \\
\hline & (2) illite \\
\hline
\end{tabular}

nepheline

(2) illite

kentbrooksite (eudialyte group) $\quad$ zircon + quartz + fergusonite-(Y)

+ bastnäsite- $(\mathrm{Ce}) \pm$ parisite- $(\mathrm{Ce}) \pm$

synchysite-(Ce) \pm samarskite- $(\mathrm{Y}) \pm$

monazite- $(\mathrm{Ce}) \pm$ xenotime- $(\mathrm{Y}) \pm$

columbite-(Fe,Mn) \pm allanite-(Ce)

without direct precursor

ankerite, fluorite, bastnäsite-(Ce)

a(1), (2) and (3) signify the sequence of alteration 
1 Table 2: Ideal chemical formulae of the minerals of interest

\begin{tabular}{|c|c|}
\hline mMineral & ${\text { ideal formula }{ }^{1}}^{-}$ \\
\hline \multicolumn{2}{|l|}{ Magmatic minerals } \\
\hline aegirine (clinopyroxene) & $\mathrm{NaFeSi}_{2} \mathrm{O}_{6}$ \\
\hline annite (biotite) & $\mathrm{KFe}_{3} \mathrm{AlSi}_{3} \mathrm{O}_{10}(\mathrm{OH})_{2}$ \\
\hline riebeckite (amphibole) & $\mathrm{Na}_{2} \mathrm{Fe}_{5} \mathrm{Si}_{8} \mathrm{O}_{22}(\mathrm{OH})_{2}$ \\
\hline analcime (zeolite) & $\underline{\mathrm{NaAlSi}_{2}} \underline{\mathrm{O}_{6}} \cdot \underline{\mathrm{H}_{2}} \underline{\underline{\mathrm{O}}}$ \\
\hline \multicolumn{2}{|l|}{ Hydrothermal minerals } \\
\hline phlogopite (biotite) & $\underline{\mathrm{KMg}_{3}} \underline{\mathrm{AlSi}_{3}} \underline{\mathrm{O}}_{10} \underline{(\mathrm{OH})_{2}}$ \\
\hline clinochlore (chlorite) & $\mathrm{Mg}_{5} \mathrm{AlAlSi}_{3} \underline{\mathrm{O}}_{10}(\mathrm{OH})_{8}$ \\
\hline illite & $\left(\mathrm{K}, \mathrm{H}_{3} \mathrm{O}\right)(\mathrm{Al}, \mathrm{Mg}, \mathrm{Fe})_{2}(\mathrm{Si}, \mathrm{Al})_{4} \underline{\mathrm{O}}_{10}\left[(\mathrm{OH})_{2},\left(\mathrm{H}_{2} \mathrm{O}\right)\right]$ \\
\hline ankerite & $\mathrm{Ca}(\mathrm{Mg}, \mathrm{Fe}, \mathrm{Mn})\left(\mathrm{CO}_{3}\right)_{2}$ \\
\hline \multicolumn{2}{|l|}{ 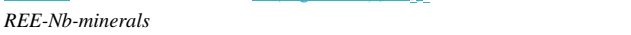 } \\
\hline fergusonite-(Y) & $\mathrm{Y}(\mathrm{Nb}, \mathrm{Ta}) \mathrm{O}_{4}$ \\
\hline bastnäsite-(Ce) & $\mathrm{CeCO}_{3} \mathrm{~F}$ \\
\hline parisite-(Ce) & $\mathrm{CaCe}_{2}\left(\mathrm{CO}_{3}\right)_{3} \mathrm{~F}_{2}$ \\
\hline synchysite-(Ce) & $\mathrm{CaCe}\left(\mathrm{CO}_{3}\right)_{2} \mathrm{~F}$ \\
\hline samarskite-(Y) & $(\mathrm{Y}, \mathrm{Ce}, \mathrm{U}, \mathrm{Fe}, \mathrm{Nb})(\mathrm{Nb}, \mathrm{Ta}, \mathrm{Ti}) \mathrm{O}_{4}$ \\
\hline columbite-(Fe,Mn) & $(\mathrm{Fe}, \mathrm{Mn})(\mathrm{Nb}, \mathrm{Ta})_{2} \mathrm{O}_{6}$ \\
\hline allanite-(Ce) & $\mathrm{CaCeAl}_{2} \mathrm{Fe}\left(\mathrm{Si}_{2} \mathrm{O}_{7}\right)\left(\mathrm{SiO}_{4}\right) \mathrm{O}(\mathrm{OH})$ \\
\hline
\end{tabular}

2 IFormulae from International Mineralogical Association (2017) and Deer et al. (1992). 
1 Table 3: Rare earth oxide powder samples used for spectral analysis $\mathrm{La}_{2} \mathrm{O}_{3}$ Lanthanum(III) oxide, REacton $®, 99.9 \%$ (REO), Alfa Aesar

$\mathrm{CeO}_{2} \quad$ Cerium(IV) oxide, REacton $囚, 99.9 \%$ (REO), Alfa Aesar

$\mathrm{Nd}_{2} \mathrm{O}_{3}$ Neodymium(III) oxide, REacton $\mathbb{8}, 99.997 \%$ (REO), Alfa Aesar

$\mathrm{Dy}_{2} \mathrm{O}_{3}$ Dysprosium(III) oxide, REacton $®$, $99.9 \%$ (REO), Alfa Aesar

$\mathrm{Gd}_{2} \mathrm{O}_{3}$ Gadolinium(III) oxide, REacton $\AA$, 99.9\% (REO), Alfa Aesar

$\mathrm{Y}_{2} \mathrm{O}_{3} \quad$ Yttrium(III) oxide, REacton $囚, 99.999 \%$ (REO), Alfa Aesar

$\mathrm{Pr}_{6} \mathrm{O}_{11}$ Praseodymium(III, IV) oxide, REacton $®$, 99.99\% (REO), Alfa Aesar

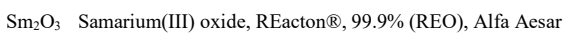

$\mathrm{Eu}_{2} \mathrm{O}_{3} \quad$ Europium(III) oxide, REacton $囚, 99.9 \%$ (REO), Alfa Aesar

$\mathrm{Tb}_{4} \mathrm{O}_{7}$ Terbium(III,IV) oxide, REacton $®$, 99.9\% (REO), Alfa Aesar

$\mathrm{Ho}_{2} \mathrm{O}_{3}$ Holmium(III) oxide, REacton $®$, 99.9\% (REO), Alfa Aesar

$\mathrm{Er}_{2} \mathrm{O}_{3}$ Erbium (III) oxide, REacton $\circledast, 99.9 \%$ (REO), Alfa Aesar

$\mathrm{Tm}_{2} \mathrm{O}_{3}$ Thulium(III) oxide, REacton ${ }^{\circledR}, 99.9 \%$ (REO), Alfa Aesar

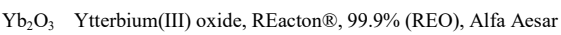

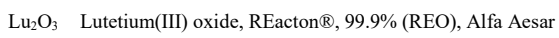

Möller, V. and A. E. Williams-Jones. "A Hyperspectral Study (V-Nir-Swir) of the Nechalacho Ree-Nb-Zr Deposit, Canada." Journal of Geochemical Exploration 188 (May 2018): 194-215. http://dx.doi.org/10.1016/j.gexplo.2018.01.011. 
1 Table 4: X-ray diffraction analyses of micas that replaced sodalite.

$$
10 \AA(001)
$$

$$
5 \AA(002) \quad \text { c.p.s. }(5 \AA) /
$$

\begin{tabular}{lccccl} 
& FWHM $\left({ }^{\circ}\right)$ & net height (c.p.s.) & net height (c.p.s.) & c.p.s. $(10 \AA)$ & identification \\
\hline L10-251-292.0 & 0.23 & 799 & 169 & 0.21 & biotite + muscovite \\
L11-329-70.75 & 0.23 & 1016 & 279 & 0.27 & phengite \\
L11-329-81.5 & 0.38 & 810 & 287 & 0.35 & phengite \\
L12-475-82.0 & 0.50 & 920 & 407 & 0.44 & muscovite-Al / illite \\
L12-475-107.3 & 0.40 & 683 & 245 & 0.36 & phengite / illite \\
L12-475-246.3 & 0.24 & 606 & 115 & 0.19 & biotite + muscovite \\
\hline
\end{tabular}

2

Möller, V. and A. E. Williams-Jones. "A Hyperspectral Study (V-Nir-Swir) of the Nechalacho Ree-Nb-Zr Deposit, Canada." Journal of Geochemical Exploration 188 (May 2018): 194-215. http://dx.doi.org/10.1016/j.gexplo.2018.01.011. 
1 Table 5: Composition of hydrothermal amphibole from the Nechalacho Layered Suite, based on electron microprobe 2 analyses.

\begin{tabular}{|c|c|c|c|}
\hline$w t . \%$ & $\begin{array}{c}\mathrm{L} 10-251-335.7(\mathrm{~N}=9) \\
\text { riebeckite }\end{array}$ & $\begin{array}{c}\text { L10-251-339.2 }(\mathrm{N}=7) \\
\text { calcian riebeckite }\end{array}$ & $\begin{array}{c}\text { L09-194-635.3 }(\mathrm{N}=1) \\
\text { arfvedsonite }\end{array}$ \\
\hline $\mathrm{SiO}_{2}$ & 49.97 & 50.70 & 50.98 \\
\hline $\mathrm{TiO}_{2}$ & $<0.09$ & $<0.10$ & $<0.10$ \\
\hline $\mathrm{Al}_{2} \mathrm{O}_{3}$ & 0.64 & 0.56 & 0.64 \\
\hline $\mathrm{Cr}_{2} \mathrm{O}_{3}$ & $<0.09$ & $<0.09$ & $<0.09$ \\
\hline $\mathrm{Fe}_{2} \mathrm{O}_{3}{ }^{\mathrm{a}}$ & 10.85 & 11.96 & 13.32 \\
\hline $\mathrm{FeO}^{\mathrm{a}}$ & 25.69 & 23.93 & 21.74 \\
\hline $\mathrm{MnO}$ & 0.22 & 0.43 & 0.34 \\
\hline $\mathrm{MgO}$ & 1.24 & 1.91 & 2.79 \\
\hline $\mathrm{ZnO}$ & & $<0.11$ & $<0.11$ \\
\hline $\mathrm{CaO}$ & 2.83 & 3.15 & 0.64 \\
\hline $\mathrm{Na}_{2} \mathrm{O}$ & 5.69 & 5.20 & 7.51 \\
\hline $\mathrm{K}_{2} \mathrm{O}$ & 0.65 & 0.55 & 0.90 \\
\hline $\mathrm{F}$ & $<0.15$ & $<0.15$ & 0.38 \\
\hline $\mathrm{Cl}$ & $<0.02$ & $<0.02$ & $<0.02$ \\
\hline $\mathrm{H}_{2} \mathrm{O}^{\mathrm{b}}$ & 1.90 & 1.93 & 1.77 \\
\hline Sum & 99.67 & 100.34 & 100.99 \\
\hline $\mathrm{O}=\mathrm{F}, \mathrm{Cl}$ & 0.00 & 0.00 & 0.16 \\
\hline Total & 99.67 & 100.34 & 100.83 \\
\hline
\end{tabular}

\begin{tabular}{llll} 
a.p.f.u. & & & \\
$\mathrm{Si}$ & 7.883 & 7.885 & 7.854 \\
$\mathrm{Al}^{\mathrm{IV}}$ & 0.117 & 0.103 & 0.116 \\
$\mathrm{Al}^{\mathrm{VI}}$ & 0.002 & 0.000 & 0.000 \\
$\mathrm{Fe}^{3+}$ & 1.288 & 1.400 & 1.544 \\
$\mathrm{Fe}^{2+}$ & 3.389 & 3.112 & 2.801 \\
$\mathrm{Mn}$ & 0.029 & 0.057 & 0.044 \\
$\mathrm{Mg}$ & 0.292 & 0.443 & 0.640 \\
$\mathrm{Ca}$ & 0.478 & 0.525 & 0.106 \\
$\mathrm{Na}$ & 1.741 & 1.567 & 2.243 \\
$\mathrm{~K}$ & 0.130 & 0.109 & 0.177 \\
$\mathrm{~F}$ & & & 0.185 \\
$\mathrm{OH}$ & 2.000 & 2.000 & 1.815 \\
\cline { 2 - 4 } Total & 17.349 & 17.202 & 17.526 \\
\hline
\end{tabular}

Mineral formula in atoms per formula unit (a.p.f.u.), calculated based on 23 oxygen and 13

cations. See Electronic Appendix E for the full data set.

a recalculated ferric and ferrous iron.
calions. See Electronic Appendix E

${ }^{\mathrm{b}}$ calculated. 


\section{$1 \quad$ Figures}

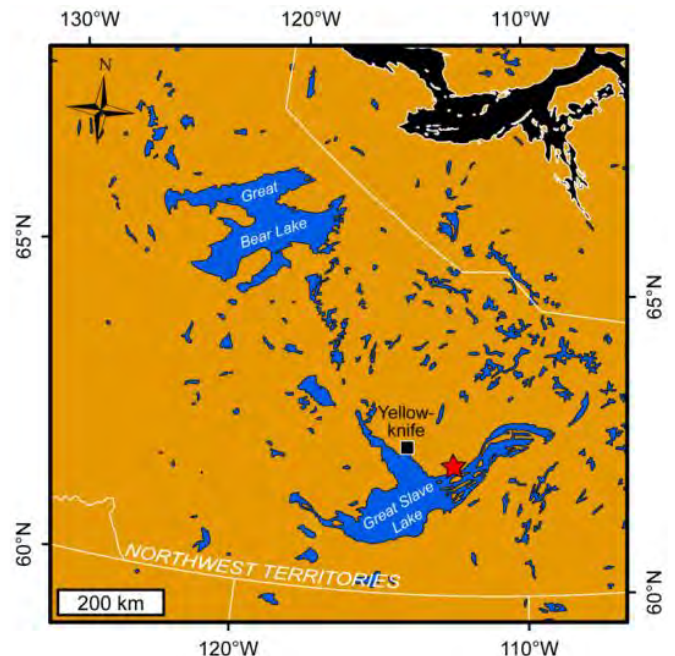

Fig. 1. Location map for the Nechalacho deposit (indicated by the red star), Northwest Territories, Canada. 


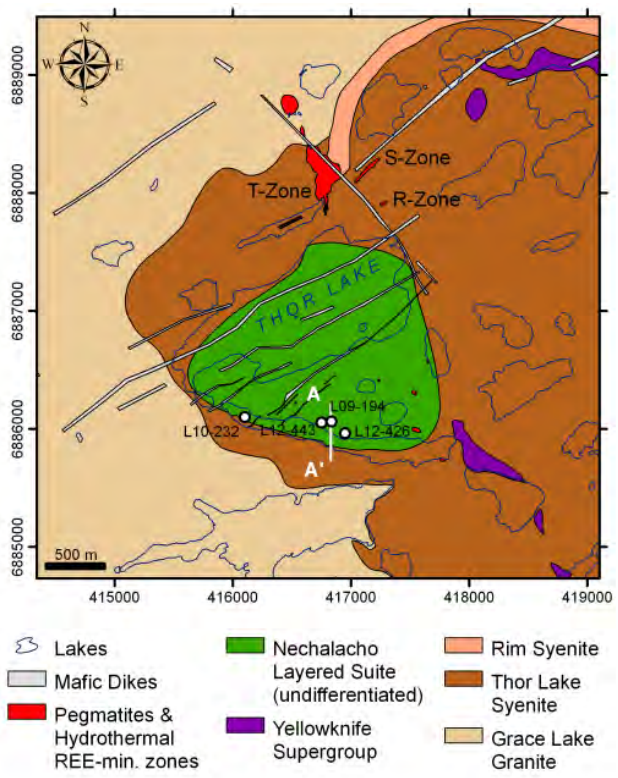

Fig. 2. Geological map (simplified from Möller and Williams-Jones, 2016a), indicating the locations of the drill holes and cross section discussed in the text and shown in Figures 15 and 20. The coordinates are given as NAD83 UTM Zone $12 \mathrm{~N}$. 

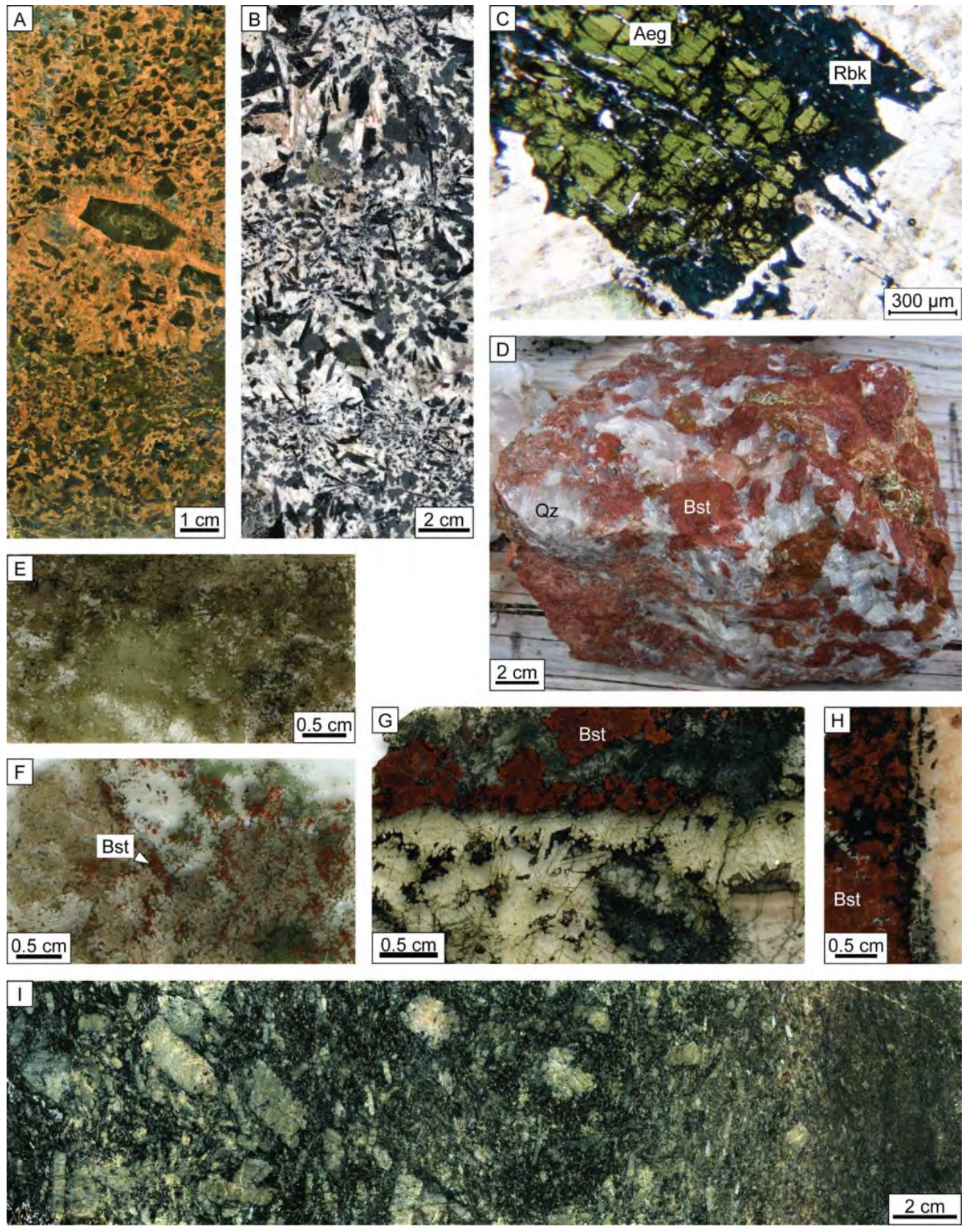

Fig. 3. Scanned rock sections (A, B, I), photograph (D), photomicrograph (C) and scanned thin sections (E, F, G, H) of altered rocks from the Nechalacho Layered Suite. A. Pseudomorphic replacement of illite (dark green) after sodalite in 
a matrix of orange K-feldspar (sample L11-329-81.5, unit NLS-1). B. Near-complete pseudomorphic replacement of aegirine (green) by riebeckite (dark blue). Potassium feldspar and albite (both white) are largely unaltered (L10-251335.7). C. Partial replacement of aegirine by riebeckite (L10-251-339.2). D. Coarse-grained bastnäsite-(Ce) (Bst) intergrown with quartz $(\mathrm{Qz})$ from the T-Zone. E. A s Strongly biotitized sample from the Basal Zone. The biotite is greenish and the eudialyte pseudomorphs brown (L10-260-121.24). F. Hydrothermal bastnäsite-(Ce) (red) next to green chlorite and beige-brown eudialyte pseudomorphs in the Upper Zone (L11-330-121.65). G and H. Hydrothermal bastnäsite-(Ce) associated with biotite (samples L10-267-77.3 and L10-271-71.06, both Upper Zone). I. Biotitized fFoyaite (L11-382-167.0, NLS-4). 

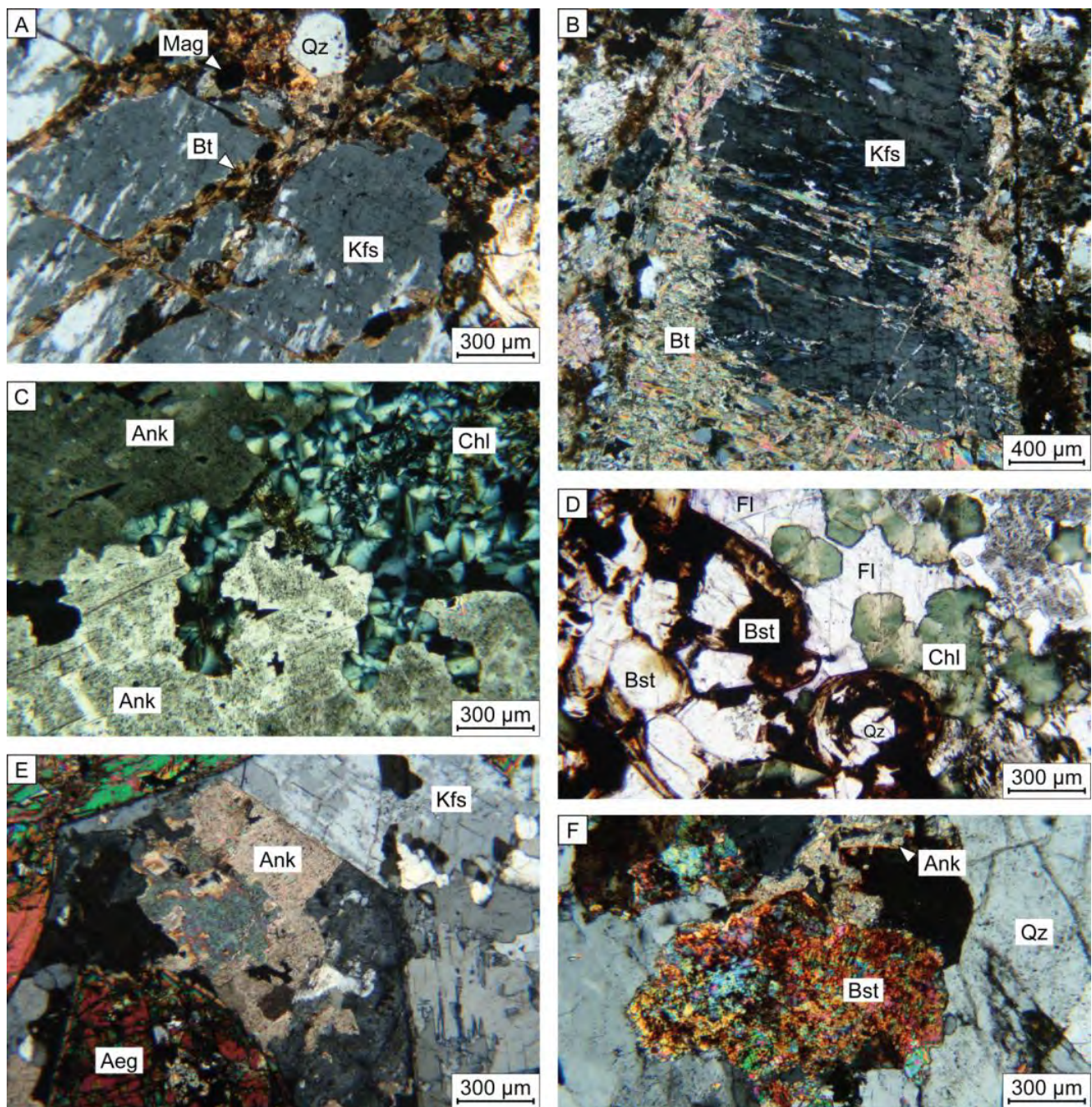

Fig. 4. Thin section photomicrographs of hydrothermally altered samples from the Nechalacho Layered Suite. A. Partial replacement of magmatic K-feldspar by hydrothermal biotite, quartz and magnetite (sample L09-160-123.7, unit NLS-6, cross-polarized light, XPL). B. Strong biotitization of K-feldspar (L11-373-305.5, NLS-6, XPL). C. Hydrothermal ankerite and chlorite (L11-330-121.65, NLS-5, XPL, see Fig. 3Fig. 3 F for an macroscopic overview of the sample). D. Euhedral hydrothermal bastnäsite-(Ce) next adjacent to chlorite, fluorite and quartz (L11-330121.65, plane-polarized light). E. Hydrothermal ankerite in a partially altered sample of the Basal Zone, which contains fresh magmatic aegirine (L12-426-176.6, NLS-6). F. Hydrothermal bastnäsite-(Ce) and ankerite in an alteration zone (TARTRE-2). 


\begin{tabular}{|c|c|c|c|c|c|}
\hline \multicolumn{6}{|c|}{ Terraspec 4 Mineral Analyzer (V-NIR-SWIR) } \\
\hline & & \multicolumn{4}{|c|}{$\begin{array}{r}\text { PIMA } \\
\end{array}$} \\
\hline X-ray & UV & visible & NIR (near infrared) & SWIR (short wavelength infrared) & $\begin{array}{l}\text { MWIR (mid wave- } \\
\text { length infrared) }\end{array}$ \\
\hline & $0 \mathrm{~nm}$ & $400 \mathrm{~nm}$ & $00 \mathrm{~nm}$ & $\begin{array}{c}\mathrm{Al}-\mathrm{OH} \\
\mathrm{Fe}-\mathrm{C}-\mathrm{O} \\
\mathrm{Mg}- \\
\mathrm{OH}\end{array}$ & $00 \mathrm{~nm}$ \\
\hline
\end{tabular}

Fig. 5. Wavelength range of the Terraspec 4 Mineral Analyzer $(350-2500 \mathrm{~nm})$ compared to that of the Portable Infrared Mineral Analyzer (PIMA). The lower and higher spectral wavelength ranges are also shown for reference. 


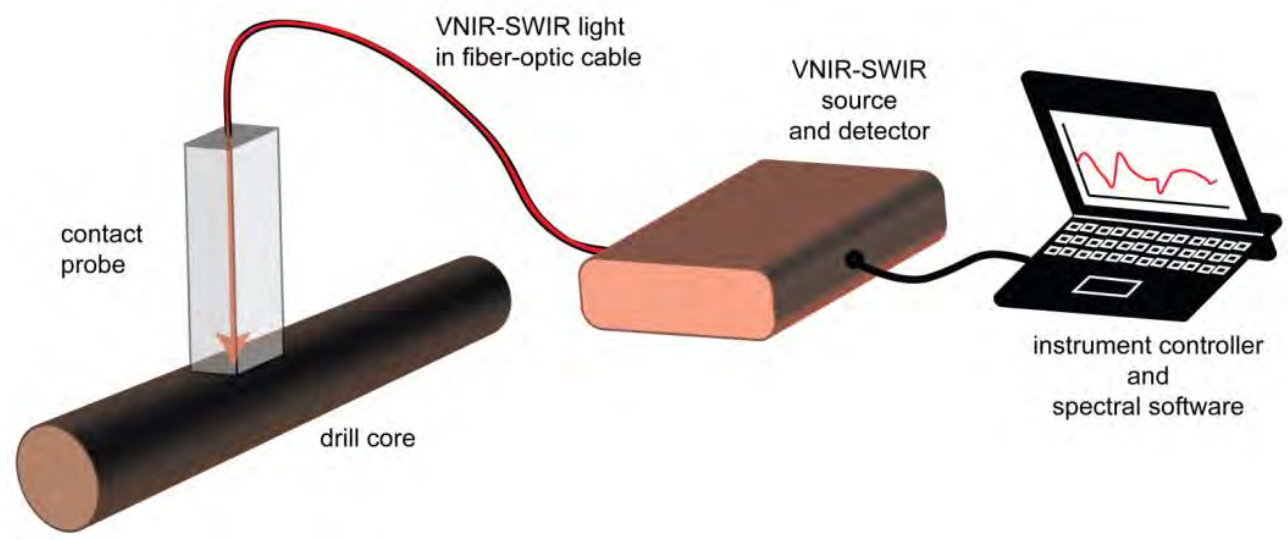

Fig. 6. Schematic representation of the field-portable V-NIR-SWIR spectroscopic system. 


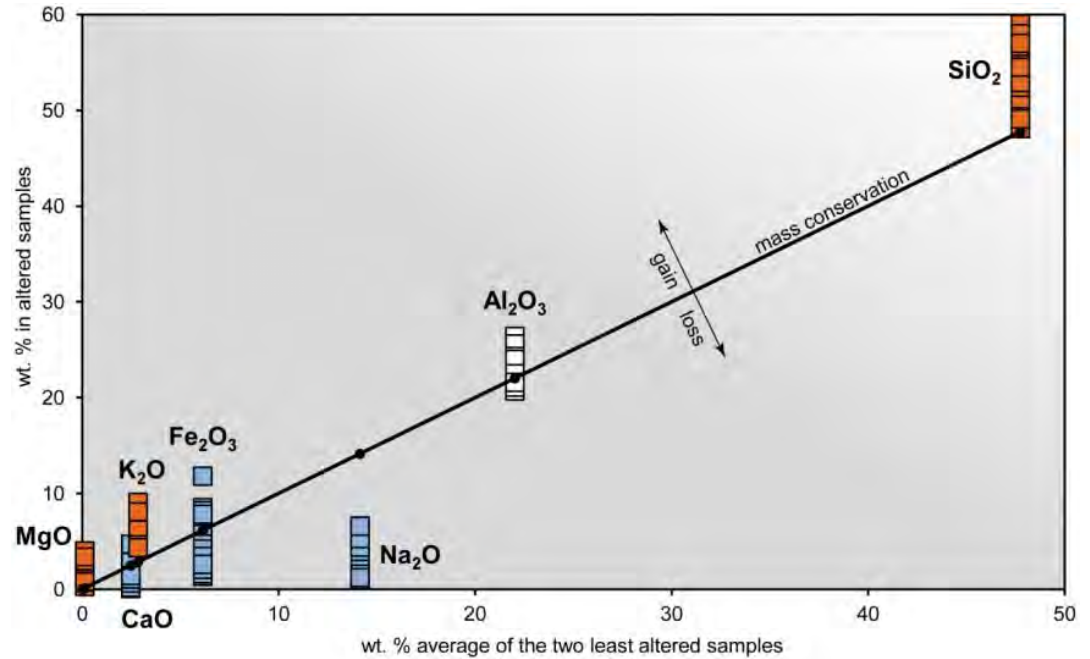

Fig. 7. Visual representation of the qualitative major element alteration mass balance for the Roof Sodalite Syenite (unit NLS-1). The diagram was constructed by plotting selected element concentrations of 47 altered samples on the Yaxis against the average of the two least-altered samples (X-axis). The solid line represents mass conservation of the average of the two least altered samples. Elements with concentrations above this line have undergone mass gain during alteration and those with concentrations below the line have undergone mass loss. See Electronic Appendix C for the geochemical analyses. 

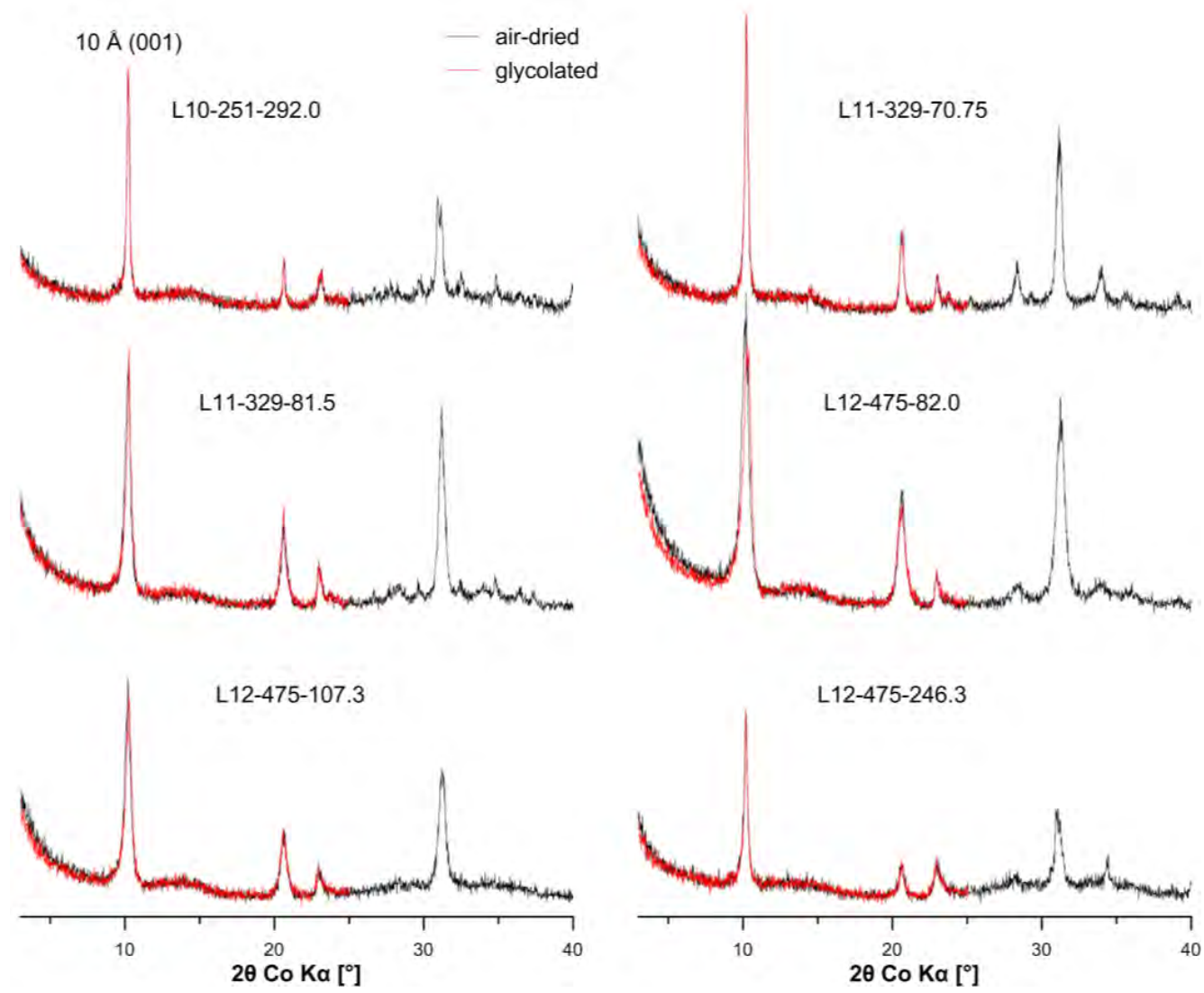

Fig. 8. X-ray diffractograms of illite series minerals that replaced sodalite. 

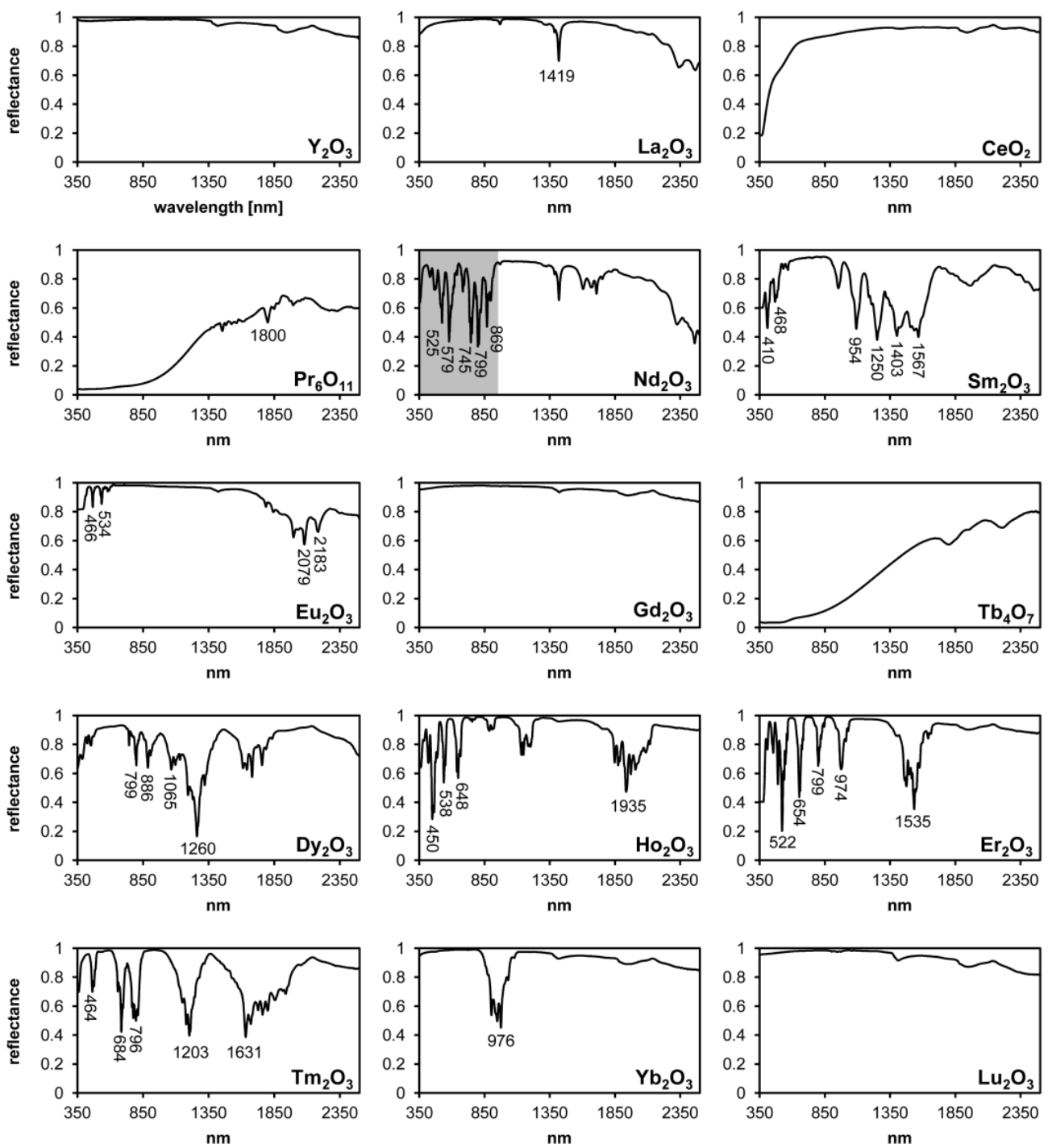

Fig. 9. Reflectance spectra for pure REE-oxide powders (see Table 3 Table 3 for the material descriptions). Some of the strong and sharp absorption features are labeled. 


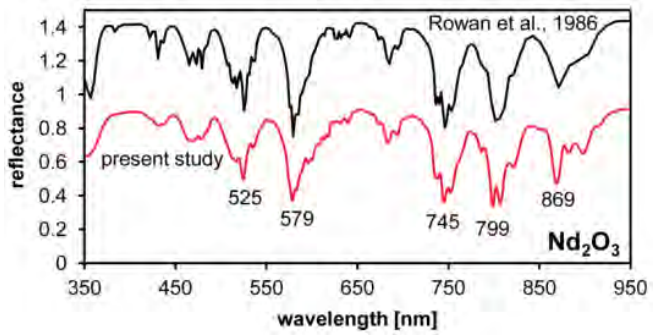

Fig. 10. Magnified view of the 350 to $950 \mathrm{~nm}$ wavelength range for $\mathrm{Nd}_{2} \mathrm{O}_{3}$ (shaded area in Fig. 9Fig. 9). Also shown is the spectrum of reagent-grade $\mathrm{Nd}_{2} \mathrm{O}_{3}$ from Rowan et al. (1986), plotted from the database of Clark et al. (1993) and offset to higher reflectance by 0.5 units. 

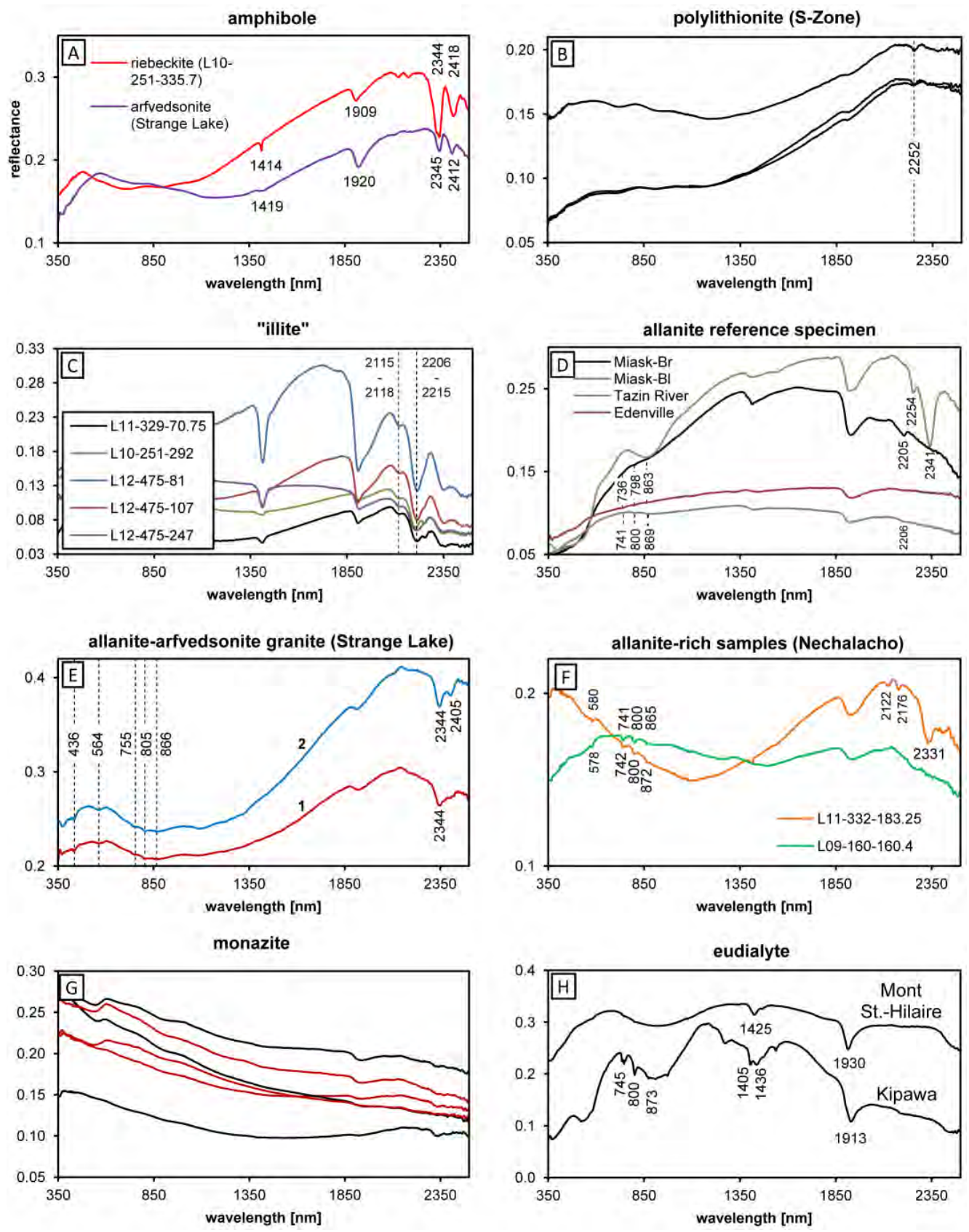

Fig. 11. Spectra of select reference specimens. A. Hydrothermal amphibole (riebeckite) from the Nechalacho Layered Suite and magmatic amphibole (arfvedsonite) from Strange Lake. B. Polylithionite from the S-Zone pegmatite. C. Illite 
from the Nechalacho Layered Suite. D. Allanite reference specimen. Two analyses of the same sample from Miask are shown, one of the brown matrix (Miask-Br) and one of a black mineral (Miask-Bl). E. Two analyses of arfvedsonitegranite containing green allanite (Strange Lake, sample ID 13210027-24, provided by Alexander Gysi). F. Allanite-rich samples from the Nechalacho Layered Suite. G. Monazite-bearing samples from the Nechalacho Layered Suite (L10305-152.2, L10-305-153.4, L10-308-202.6, L10-308-204.0, L10-308-205.2, L10-308-206.1). Samples with Ndabsorptions (weak) are shown in dark red. H. Eudialyte from the Kipawa and Mont Saint-Hilaire intrusions. 

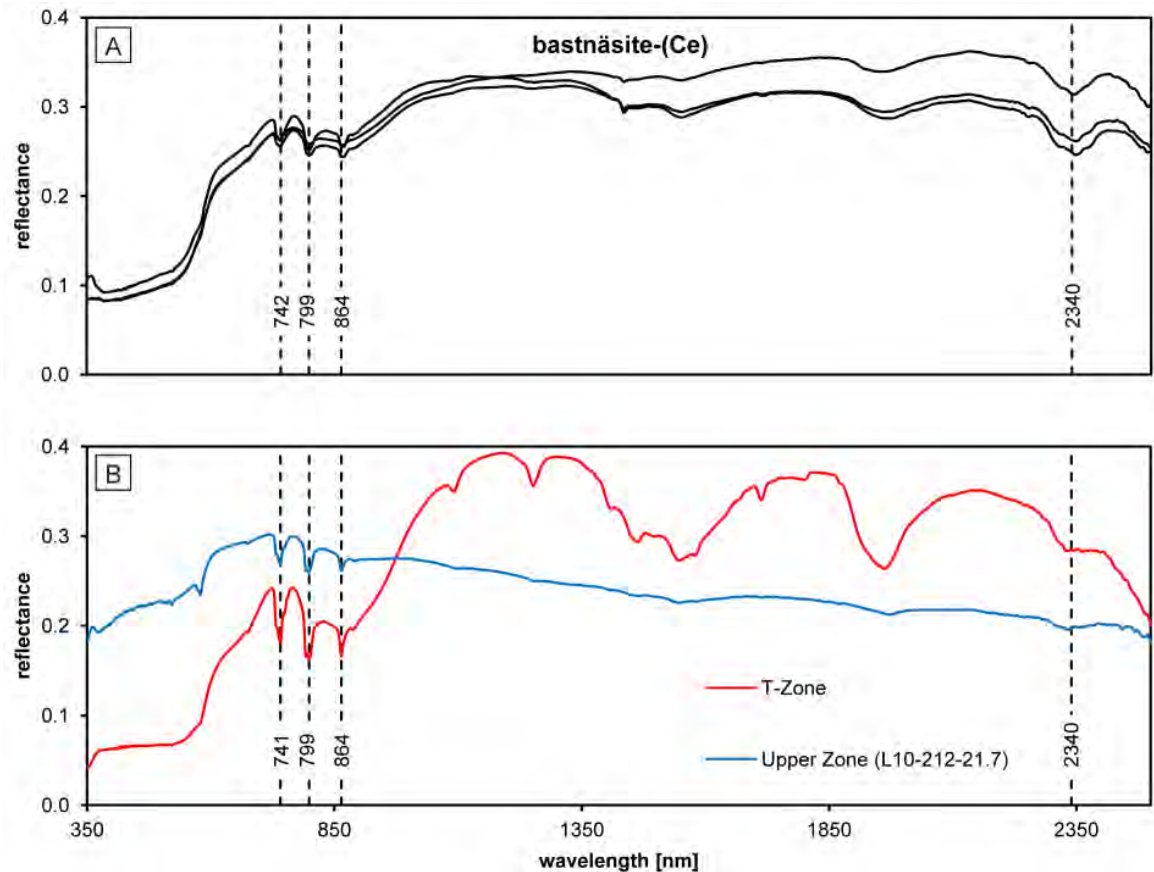

Fig. 12. Reflectance spectra for bastnäsite-(Ce) A. from Mountain Pass (three different spots were analyzed in the same sample), and B. from the T-Zone and from the Upper Zone of the Nechalacho deposit. 


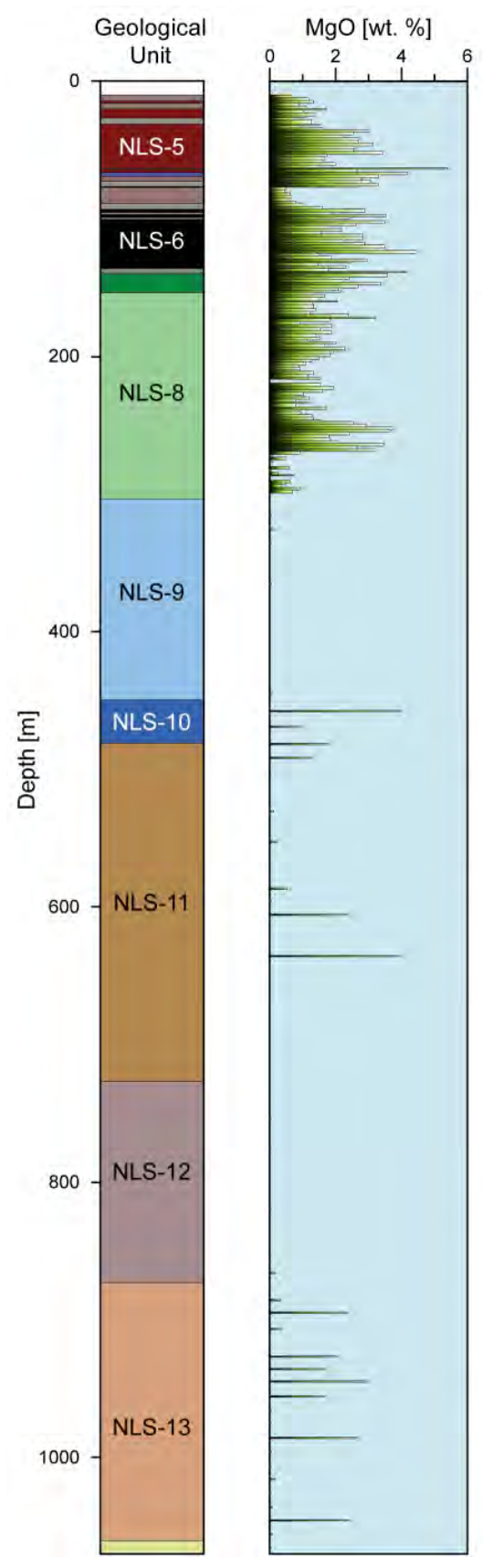

Magn. susceptibility $\chi_{v}$

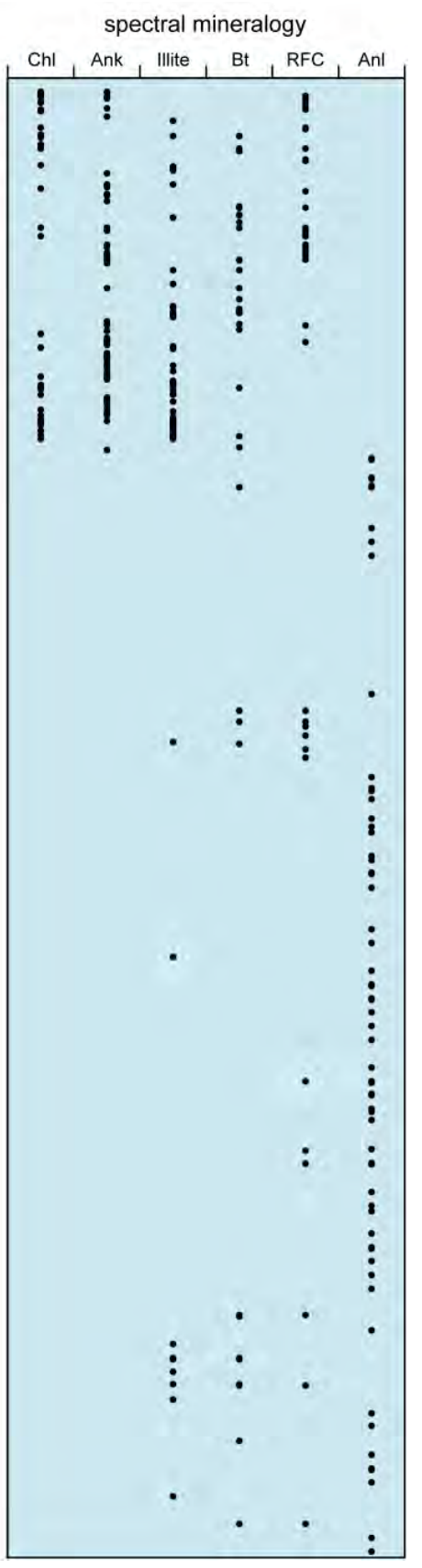

45

Möller, V. and A. E. Williams-Jones. "A Hyperspectral Study (V-Nir-Swir) of the Nechalacho Ree-Nb-Zr Deposit, Canada." Journal of Geochemical Exploration 188 (May 2018): 194-215. http://dx.doi.org/10.1016/j.gexplo.2018.01.011. 
Fig. 13. Lithology, $\mathrm{MgO}$ concentration, magnetic susceptibility and mineralogy based on spectral analyses of core from drill hole L09-194 (see Fig. 2 for the location). The bulk rock analyses are from Möller and Williams-Jones (2016a). Mineral abbreviations: chlorite $=\mathrm{Chl}$, ankerite $=\mathrm{Ank}$, biotite $=\mathrm{Bt}$, REE-fluorocarbonates (undifferentiated) $=\mathrm{RFC}$, analcime $=$ Anl.

Möller, V. and A. E. Williams-Jones. "A Hyperspectral Study (V-Nir-Swir) of the Nechalacho Ree-Nb-Zr Deposit, Canada." Journal of Geochemical Exploration 188 (May 2018): 194-215. http://dx.doi.org/10.1016/j.gexplo.2018.01.011. 


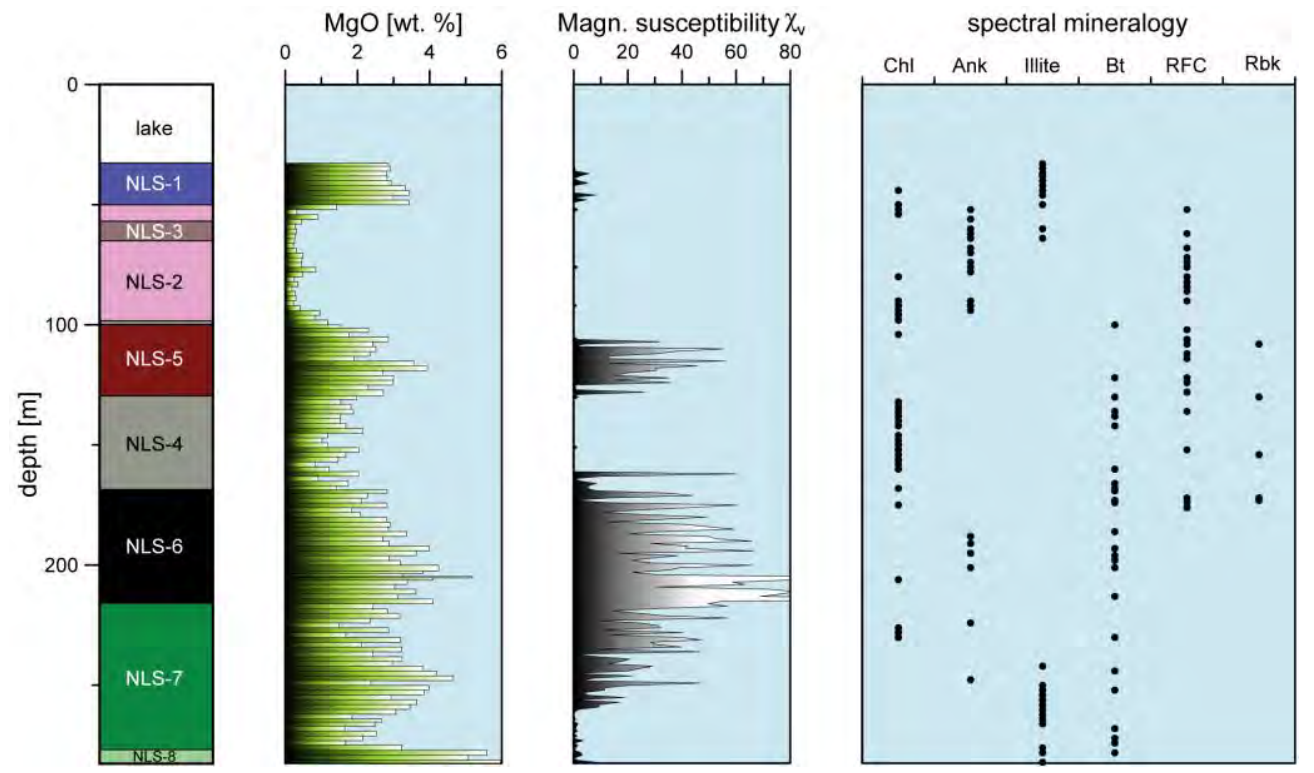

Fig. 14. Hydrothermal mineralogy deduced from spectral data for drill hole L10-232 (see Fig. 2 for the location). Also shown are the primary geology and the alteration intensity proxies, $\mathrm{MgO}$ and magnetic susceptibility. The mineral abbreviations are as in Fig. 13Figure. 13. 


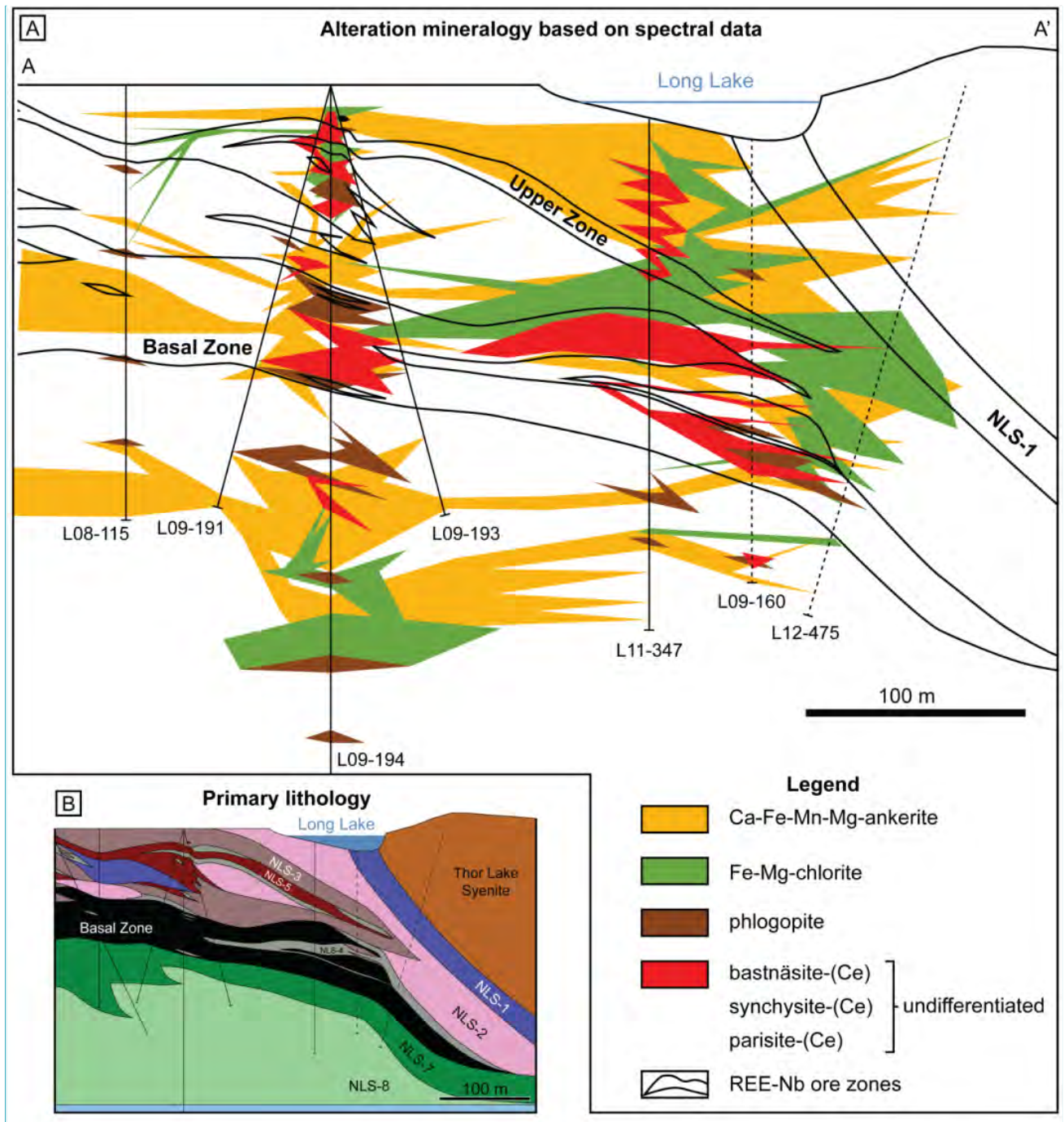

Commented [VM5]: there could be some edge effects on the zones, like fading etc. to make it look better. maybe shadows?

Fig. 15. Cross section at the southern outer contact of the Nechalacho Layered Suite intrusion under Long Lake (see Fig. 2 for the section location). A. Hydrothermal alteration mineralogy based on hyperspectral analyses. B. Primary magmatic-igneous geology interpolated from diamond drill hole logs (detailed core descriptions; see Möller and Williams-Jones, 2016a for a description of the lithological units). The outlines of the mineralized zones are based on a 1 wt. \% REE-oxide assay cut-off and geological logging. 

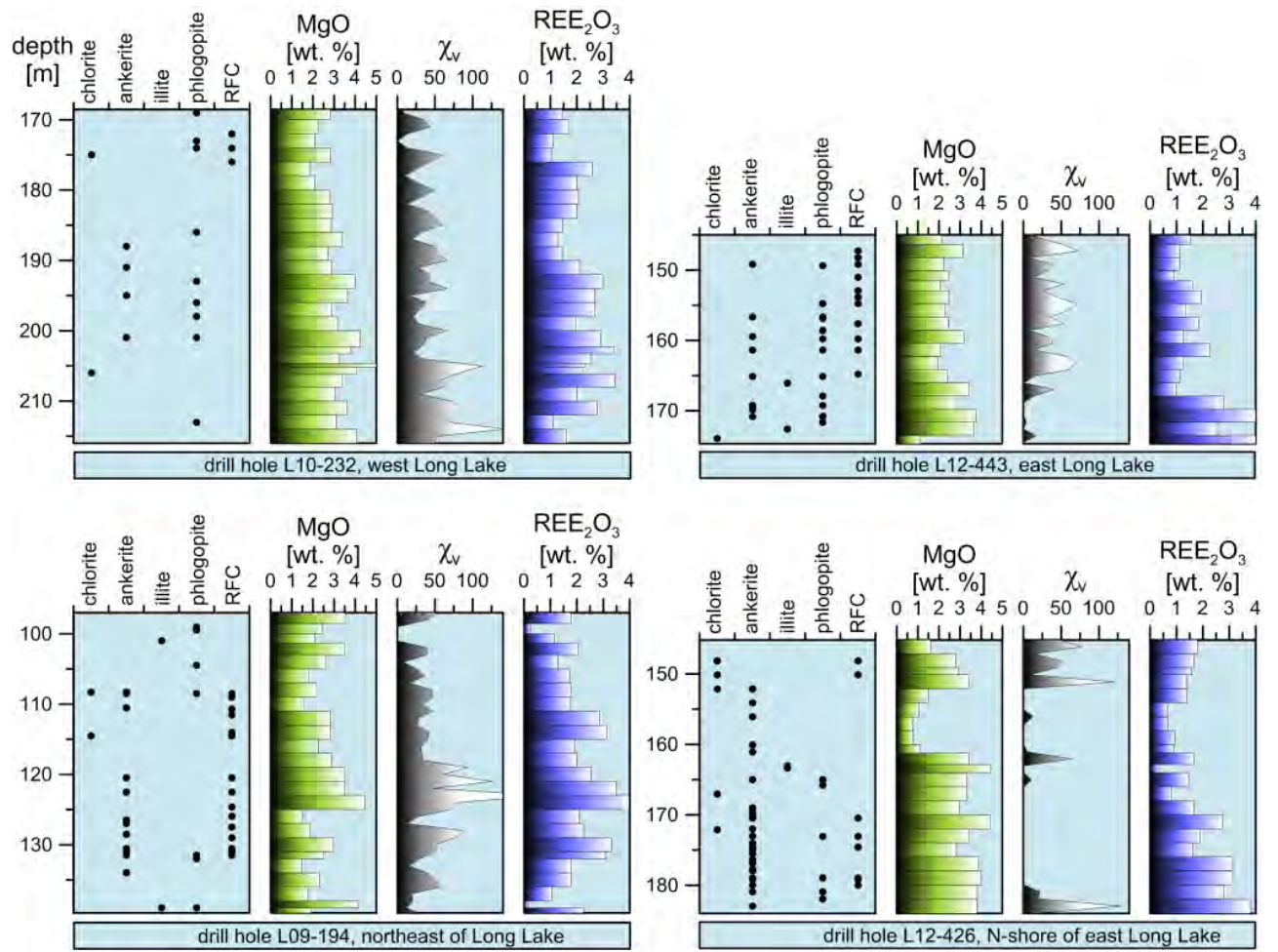

Fig. 16. Alteration mineralogy of the Basal Zone based on spectral analyses. The individual various REEfluorocarbonate mineralss (RFC) were grouped together. Also shown is the magnetic susceptibility $\chi_{\mathrm{v}}$ as a proxy for the abundance of hydrothermal magnetite, the concentration of $\mathrm{MgO}$ in weight \% (wt. \%), which traces the hydrothermal Mg-input, and the total $\mathrm{REE}_{2} \mathrm{O}_{3}$ concentration (geochemical data from Möller and Williams-Jones, 2016a; additional data are reported in Electronic Appendix C). Spectral analyses were recorded every $1 \mathrm{~m}$ in drill holes L10-232, L12426, L12-443 and every $0.5 \mathrm{~m}$ in drill hole L09-194. Select additional samples were analyzed in drill holes L09-194, L12-426 and L12-443. The depths represent true vertical depths. 

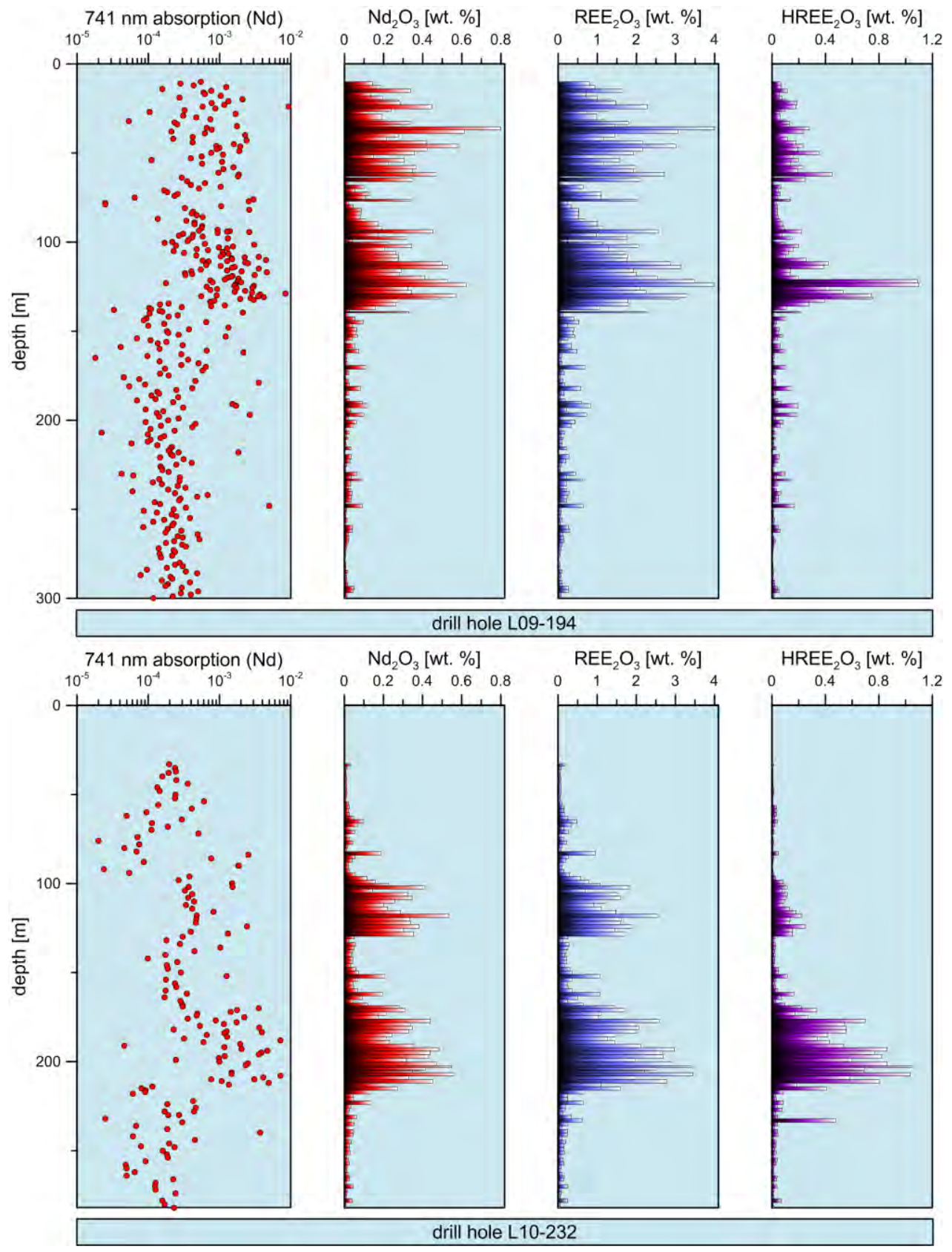

Fig. 17. Downhole comparison of the relative absorption depth of the $741 \mathrm{~nm}$ feature (elemental absorption by Nd, see text for the ealculation-method of calculation) to assay values. The bar heights correspond to the sample lengths. 

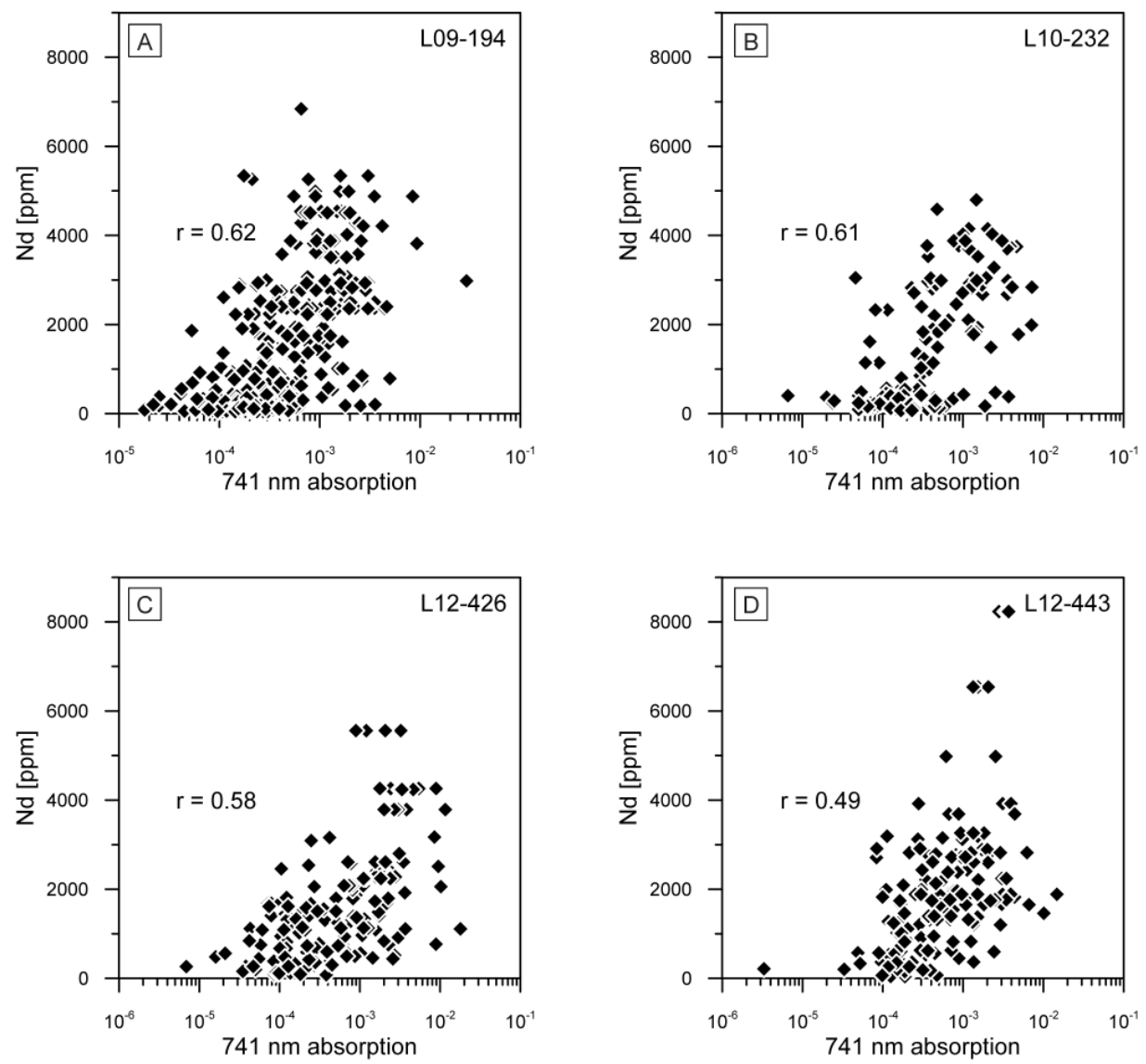

Fig. 18. Comparison of the $741 \mathrm{~nm}$ spectral absorption feature of $\mathrm{Nd}$ (relative absorption depth of the normalized hull quotient) to the corresponding bulk rock Nd concentrations measured by ICP-MS (data from Möller and WilliamsJones, 2016a). For drill hole L09-194, only the data from the top of the drill hole down to a depth of $299 \mathrm{~m}$ depth were ineludedare shown. The Pearson correlation coefficient, $r$, is shown for the two variables (log normalized absorption feature, $\mathrm{Nd}$ concentration). 


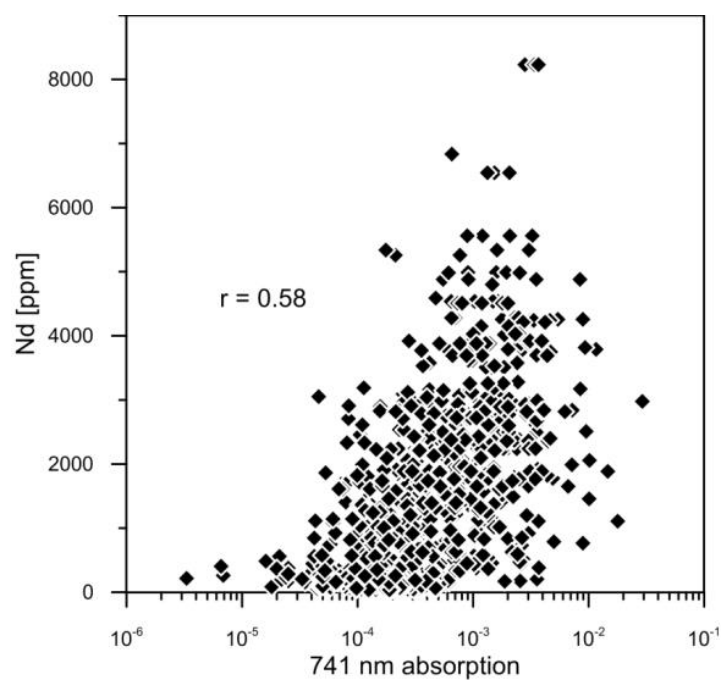

Fig. 19. Comparison of the depth of the $741 \mathrm{~nm}$ absorption feature for $\mathrm{Nd}$ to the Nd concentration in drill holes L09194, L10-232, L12-426, and L12-443 ( $\mathrm{N}=829)$. The Pearson correlation coefficient, $r$, is notedindicated. 


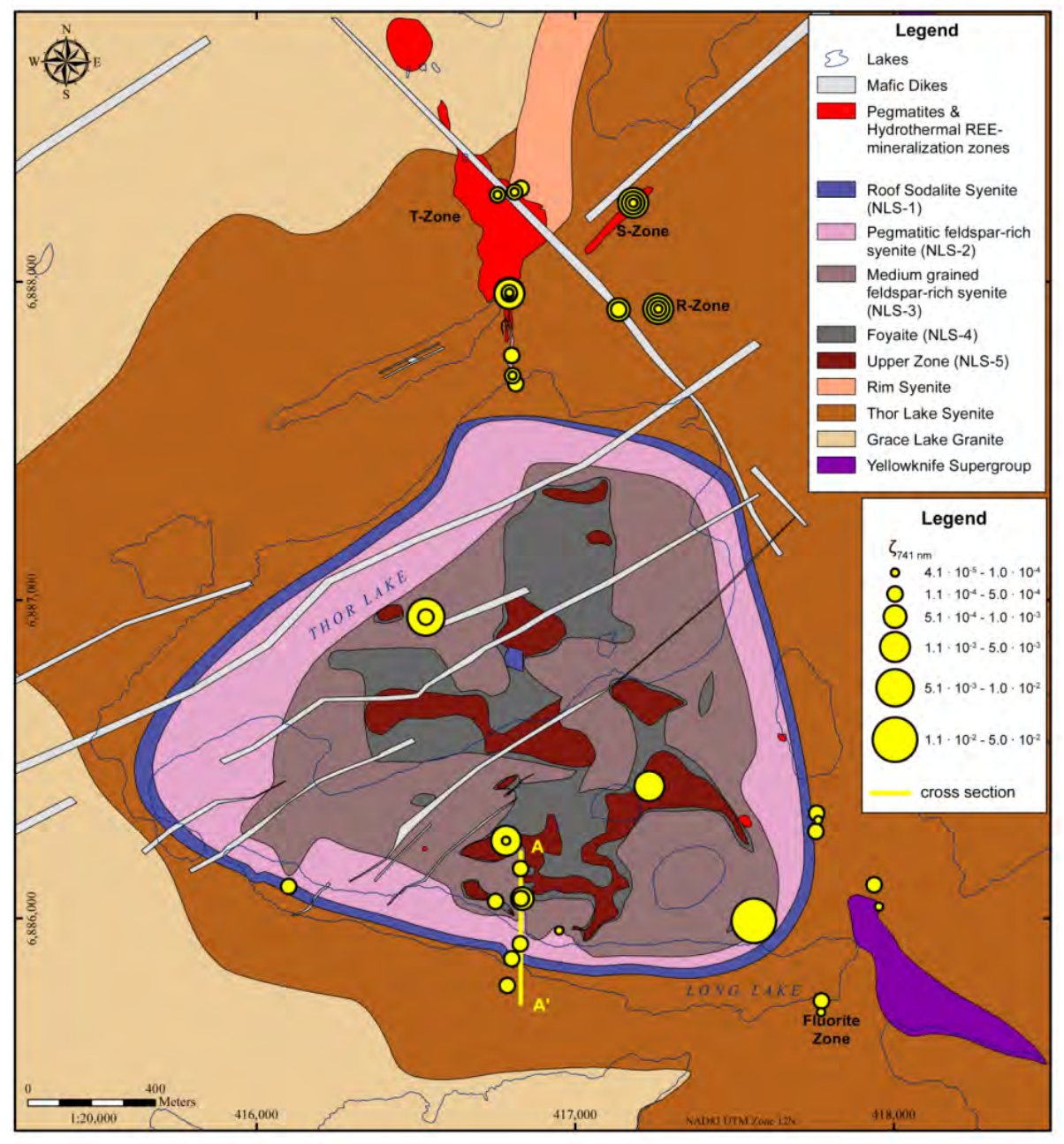

Fig. 20. Geological map from Möller and Williams-Jones (2016a) with an overlay of the relative absorption depth of the $741 \mathrm{~nm}$ absorption feature of $\mathrm{Nd}\left(\zeta_{741 \mathrm{~nm}}\right)$ for 64 outcrop samples and the uppermost core samples of 11 drill holes. Also shown is the location of the cross section employed-illustrated in Figure 15. 